\title{
Aerosol Absorption: Progress Towards Global and Regional Constraints
}

\author{
Bjørn H. Samset ${ }^{1} \cdot$ Camilla W. Stjern $^{1} \cdot$ Elisabeth Andrews ${ }^{2} \cdot$ Ralph A. Kahn $^{3} \cdot$ Gunnar Myhre $^{1} \cdot$ Michael Schulz $^{4}$. \\ Gregory L. Schuster ${ }^{5}$
}

Published online: 3 April 2018

(C) The Author(s) 2018

\begin{abstract}
Purpose of Review Some aerosols absorb solar radiation, altering cloud properties, atmospheric stability and circulation dynamics, and the water cycle. Here we review recent progress towards global and regional constraints on aerosol absorption from observations and modeling, considering physical properties and combined approaches crucial for understanding the total (natural and anthropogenic) influences of aerosols on the climate.

Recent Findings We emphasize developments in black carbon absorption alteration due to coating and ageing, brown carbon characterization, dust composition, absorbing aerosol above cloud, source modeling and size distributions, and validation of high-resolution modeling against a range of observations.

Summary Both observations and modeling of total aerosol absorption, absorbing aerosol optical depths and single scattering albedo, as well as the vertical distribution of atmospheric absorption, still suffer from uncertainties and unknowns significant for climate applications. We offer a roadmap of developments needed to bring the field substantially forward.
\end{abstract}

Keywords Aerosols $\cdot$ Absorption $\cdot$ Black carbon $\cdot$ Brown carbon $\cdot$ Mineral dust $\cdot$ Climate

\section{Introduction}

Improving constraints on aerosol absorption of light is a key challenge for current atmospheric research. Although it has long been known that some aerosol species perturb the energy balance of the atmospheric column through shortwave absorption, affecting radiative forcing, cloud formation, precipitation, and more, the magnitude of these effects has proven

This article is part of the Topical Collection on Aerosols and Climate

Electronic supplementary material The online version of this article (https://doi.org/10.1007/s40641-018-0091-4) contains supplementary material, which is available to authorized users.

Bjørn H. Samset

b.h.samset@ cicero.oslo.no

1 CICERO Center for International Climate Research, Oslo, Norway

2 CIRES, University of Colorado, Boulder, CO, USA

3 Earth Sciences Division, NASA Goddard Space Flight Center, Greenbelt, MD 20771, USA

4 Norwegian Meteorological Institute, Oslo, Norway

5 NASA Langley Research Center, Hampton, VA, USA difficult to pin down. A 2009 review paper [1] concluded that although progress was rapid, "there is need for much additional work in characterizing aerosol light absorption in the atmosphere and its effects on radiative forcing and visibility." Despite a subsequent decade of active research and considerable progress, this statement is still generally true. However, recent developments and suggestions for future observations show great promise, indicating that better constraints on aerosol absorption may be possible in the near future.

Aerosols affect the climate system by intercepting incoming shortwave radiation. Although all aerosols act as scatterers of radiation, reducing surface irradiance, some species also absorb, effectively adding a positive energy term to the atmospheric radiative balance. The main absorbing aerosol species are black carbon (BC) [2], mineral dust [3, 4], and the absorbing component of organic aerosols $[5,6]$, recently termed brown carbon $(\mathrm{BrC})$. Conceptually, the net shortwave aerosol absorption, usually quantified through the absorbing aerosol optical depth (AAOD), can therefore be thought of as the sum of the contributions of these three separate species, integrated over the atmospheric column. Observationally, however, such clear distinction into separate aerosol categories is usually not possible, because of mixing of aerosol species. This makes validation of model predictions challenging. 
Further, the aerosol types - however they are defineddiffer significantly in emission volumes, locations, and seasonality, in their transport and residence times in the atmosphere, and in the spectral dependence of their absorptive (and other optical) properties. Aerosol loading varies significantly with geographical location and season, and depends upon annually varying conditions such as meteorology, soil moisture, and the intensity of fire seasons. Aerosol absorption is primarily retrieved via remote sensing (e.g., satellites and ground-based sunphotometers) or measured via in situ instruments at long-term surface stations and during aircraft field campaigns. Although a wealth of observational data exists, these data are still far from sufficient to provide global and annual coverage of such diverse and rapidly varying quantities. Present efforts therefore focus on combining model calculations with observations through gap filling, assimilation techniques, and reanalysis.

In the present review, we define "constraint" as reasonable agreement between observations and theoretical or model-based estimates, combined with a quantification of the agreement and some understanding of why the two agree. We think that a reasonable agreement is achieved if global anthropogenic aerosol forcing due to aerosol radiation interactions from absorbing components could be estimated within $0.1 \mathrm{~W} \mathrm{~m}^{-2}$. To break the problem down, we first cover recent advances in modeling and observational constraints on the physical properties of individual aerosol species. Topics of particular interest are absorption changes from ageing (coating and fractal collapse) of $\mathrm{BC}$, and improved understanding of $\mathrm{BC}$ particle morphology and mixing state. For brown carbon, the main challenges are the spectral absorption dependence and ageing properties, as well as a clear distinction from $\mathrm{BC}$ and dust. For mineral dust, important issues are the uncertainties associated with composition, size, and source distribution (and changes in these properties during transport), as well as modeled source terms. Next, we cover advances in observations via remote sensing and in situ measurements, and recent reanalysis results. We also discuss a range of outstanding issues and how they currently preclude sufficient constraints on aerosol absorption to guide global or regional climate models for climate forcing applications. A roadmap towards improved constraints on aerosol absorption, as defined above, is given in Table 1. The recommendations we set out are drawn from the discussions of recent literature in the coming sections, and from discussions at topical workshops such as the annual AeroCom/AeroSAT meeting. A summary of the major topics in recent literature, including some key publications, is also provided in Supplementary Table 1.
As the present format is not suited to review the underlying theory or core experimental and numerical techniques, we refer the reader to the reviews and summaries of Moosmüller et al. [1], Bergstrom et al. [7], Petzold et al. [8], Lack et al. [9], and Stier et al. [10].

\section{Motivation}

The present lack of good constraints on aerosol absorption can significantly affect estimates of aerosol climate impact. As an example, we consider the recent Phase 2 of the AeroCom multi-model initiative. There, modelers simulated aerosol loading and radiative impacts for the same meteorological year (2006) using identical emissions (year 2000, [11]). They reported a multi-model annual mean total AAOD at $550 \mathrm{~nm}$ of $0.0042 \pm 0.0019$ (1 std.dev.), with a min-max range of [0.0021, 0.0076] (see Myhre et al. [12]). Anthropogenic AAOD at $550 \mathrm{~nm}$ was reported as $0.0015 \pm 0.0007$, with a global relative standard deviation of $\sim 50 \%$. (See further discussion of AeroCom Phase 2 below, and Fig. 2.)

To test the implications of this uncertainty for climate simulations, we modified the optical properties of $\mathrm{BC}$ in a recent climate model (CESM 1.2 using CAM5 [13] with year 2000 conditions and fixed sea-surface temperatures), by a quantity sufficient to increase the total annual mean AAOD by approximately one AeroCom Phase II standard deviation (AeroCom multi-model historical AAOD: $0.0015 \pm 0.0015$; our baseline was 0.0030 , perturbed to 0.0043). By comparing the simulated perturbed setup to one using the default CAM5 optical parameters for years 3-30, we find an instantaneous, top-of-atmosphere effective radiative forcing of up to $3 \mathrm{~W} \mathrm{~m}^{-2}$ over $\mathrm{BC}$ emission hotspots (global mean: $0.2 \mathrm{~W} \mathrm{~m}^{-2}$, which is comparable to the historical aerosol RF of the direct effect in AeroCom Phase II: $-0.27 \pm 0.15 \mathrm{~W} \mathrm{~m}^{-2}$ ). Calculation of effective radiative forcing (ERF) followed Forster et al. [14]. Even with fixed sea-surface temperatures, this forcing induces land surface temperature changes of up to + $0.5 \mathrm{~K}$ over midlatitude regions, and up to $+1 \mathrm{~K}$ over high albedo surfaces such as Greenland-far from emission regions. Notable changes are also simulated for precipitation and cloud fractions, as parts of the response to the forcing. Although this setup is idealized, and results would differ if mineral dust or brown carbon was perturbed instead of $\mathrm{BC}$, it indicates the magnitude of inter-model differences possible within the present spread of predicted AAOD. Recently, it has also been shown that $\mathrm{BC}$, as a significant contributor to atmospheric absorption, is likely a main driver of inter-model differences in 
Table 1 A roadmap towards improved constraints on aerosol absorption. A constraint is here defined as agreement between observational and theoretical/ modeling estimates, and some understanding of why they agree. The table lists developments that, in our view, are key to bringing the field forward

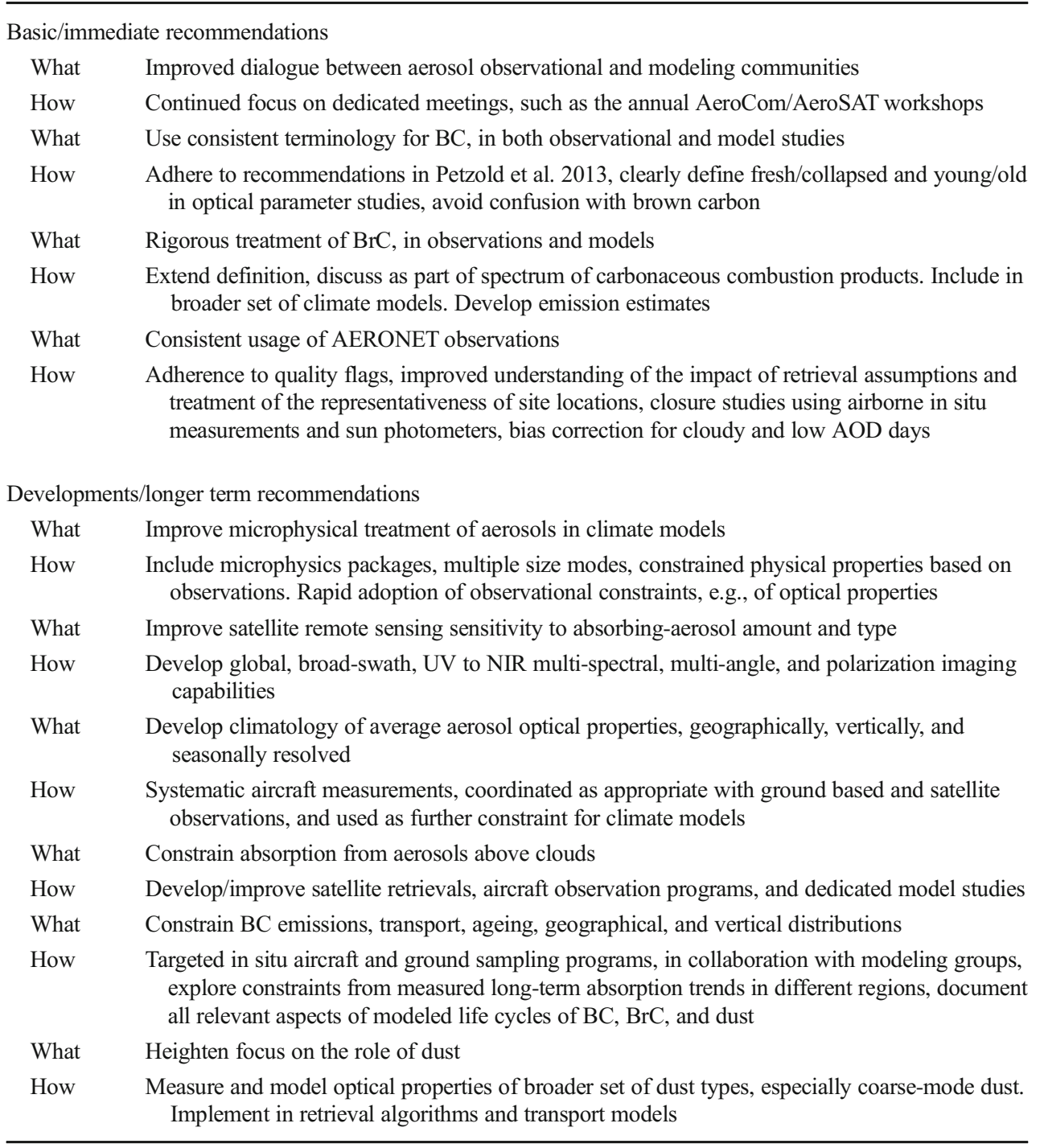

precipitation predictions $([15,16])$. In our simplified simulation mentioned above, atmospheric column energy absorption also changed by up to $5 \mathrm{~W} \mathrm{~m}^{-2}$ in regions with high $\mathrm{BC}$ emissions, likely affecting atmospheric stability and precipitation rates. Clearly, better constraints on AAOD would aid the development of coupled climate models.

Another notable example of the importance and understanding of aerosol absorption is the use of AAOD constraints from AErosol RObotic NETwork (AERONET) stations (to be discussed below) in a recent assessment of the climate impacts of $\mathrm{BC}$ emissions [2]. Model results were scaled to match AERONET, resulting in a marked increase in estimated global BC RF, as it was calculated using model-estimated forcing efficiencies per unit AAOD. Similar approaches are often used with various underlying assumptions about aerosol composition and corrections for regional or near-source bias.

In response to this challenge, there is considerable activity in the aerosol science community to improve knowledge of aerosol absorption. As an indication, Supplementary Fig. 1 shows the recent evolution in the number of publications within the earth sciences dealing with aerosol absorption in general and in combination with one of the major aerosol species. (For information on how the selection was made, see the figure caption.) The field has seen a doubling in the number of publications over a 15-year period. Topically, the literature is moving increasingly from discussing "aerosols" in general, to focusing on the three main absorbing species. Brown carbon has seen a sharp rise in interest after 2010, and by 2016 had almost as many publications as 
the longer standing topic of dust absorption. Interest in black carbon absorption is also at a record high.

\section{Species-Based Advances and Perspectives}

One path towards improved constraints on absorption is to treat the aerosol population as a collection of individual species - notably $\mathrm{BC}, \mathrm{BrC}$, and mineral dust. In this section, we discuss known issues and recent key insights for these species individually. Both physical and optical properties, and their implementation in present climate models, are treated. We note that although separation into the categories "BC", "BrC," and "mineral dust" makes sense in models, where separate sources and collective properties can be fully specified, such distinctions will always be idealized. E.g., $\mathrm{BC}$ and $\mathrm{BrC}$ both belong to the spectrum of carbonaceous combustion products, which can have a wide range of properties. However, there is broad agreement that, in practice, there exist general categories of absorbing aerosols that have distinct physical properties. Understanding and constraining these properties are crucial first steps towards also constraining total aerosol absorption. Figure 1 illustrates these differences, sketching the present knowledge of imaginary refractive index wavelength dependence, mass absorption coefficient (MAC), and single scattering albedo (SSA) for $\mathrm{BC}, \mathrm{BrC}$, and dust. The bands indicate, but do not exhaustively cover, values that appear in the literature. Also, Supplementary Table 1 provides a summary of the issues to be discussed below and in the next section. For a discussion on the emergent power law behavior of aerosol absorption as function of wavelength, quantified through the Absorption Ångström Exponent (AAE), see, e.g., Andersson [23].

\section{Black Carbon}

$\mathrm{BC}$ is a collective term for strongly light-absorbing, carbonaceous aerosols, arising from incomplete combustion of fossil fuels, biofuels, and biomass. $\mathrm{BC}$ is one of the aerosol species that contributes the most to atmospheric absorption under present-day conditions. Different sources and combustion temperatures give rise to variations in particle structure and shape [5, 24]. Further changes in morphology and hygroscopicity occur as $\mathrm{BC}$ particles age, and, in the process, the particles can grow and mix with other atmospheric constituents, inducing spatial and temporal variations in their optical properties.

\section{Definition and Optical Properties}

There is still significant ambiguity as to the definition of $\mathrm{BC}$ in the scientific literature. However, most recent studies adhere to the definition of Petzold et al. [8] of $\mathrm{BC}$ as "an ideally light-absorbing substance composed of carbon," and the more detailed definition by Moosmüller et al. [1] as "carbonaceous material with a deep black
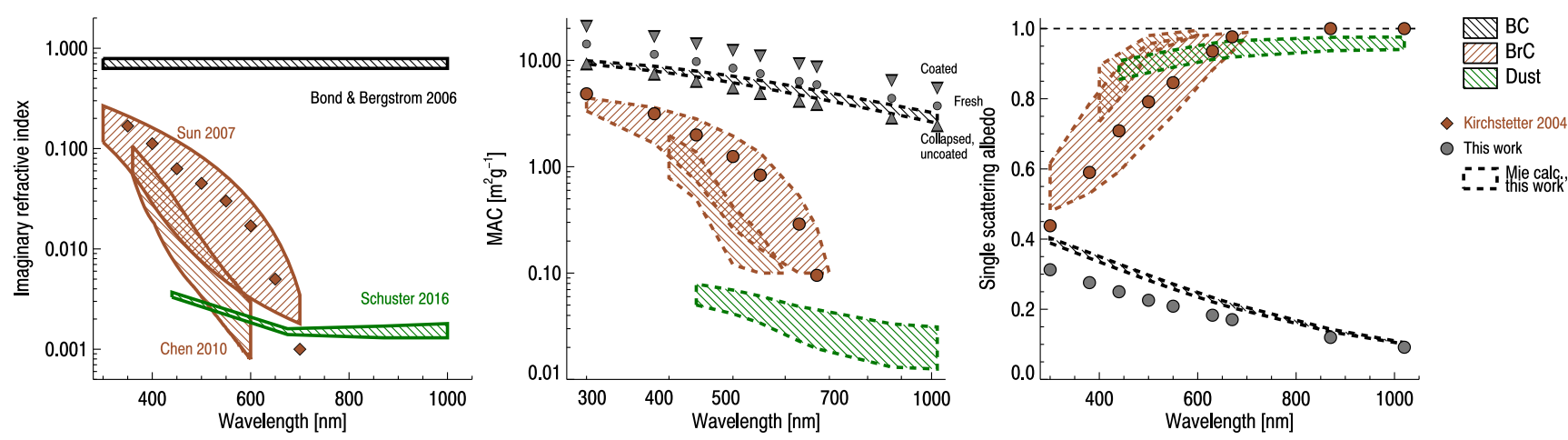

Fig. 1 Optical parameters for the three main absorbing aerosol types, with values guided by recent literature. Left: imaginary refractive index $(k)$ as function of wavelength. Values are from [17] (BC), [6, 18, 19] $(\mathrm{BrC})$, and [20] (dust). The dust values represent the range of an AeroNet-derived climatology. In the middle and right panels, the $k$ values have been used as input to Mie theory calculations, to yield consistent values for MAC and SSA. Mie calculation results are shown with dashed borders. For $\mathrm{BC}$ and $\mathrm{BrC}$, size distributions were taken from standard calculations of accumulation type aerosols [21] (Radius (NMR) and sig$\mathrm{ma}$ (GSD) of $0.04 \mu \mathrm{m}$ and 1.5 for BC, and $0.05 \mu \mathrm{m}$ and 2.0 for BrC). For mineral dust, the observed size distribution from the DABEX aerosol campaign was taken as input [22]. Aerosol densities applied in the Mie

calculations were $1.2,1.8$, and $2.6 \mathrm{~g} \mathrm{~cm}^{-3}$, for $\mathrm{BrC}, \mathrm{BC}$, and dust, respectively. Freshly emitted $\mathrm{BC}$ is often composed of aggregates, sometimes thinly coated, with a representative MAC of $7.5 \mathrm{~m}^{2} \mathrm{~g}^{-1}$. Using Mie theory with the recommended refractive indices, size distributions and density are therefore inconsistent with observed MAC of freshly emitted BC (see text for further discussion). To illustrate the optical properties of common, freshly emitted BC, we show additional MAC and SSA values (gray circles) where the Mie calculations have been scaled to achieve the recommended MAC of $7.5 \mathrm{~m}^{2} \mathrm{~g}^{-1}$ at $550 \mathrm{~nm}$. In the MAC panel, we also indicate the range of values found in the literature for coated $\mathrm{BC}$, and collapsed, uncoated BC (see main text and Supplementary Table 2) 
appearance, which is caused by a significant, nonzero imaginary part ... of the refractive index that is wavelength independent over the visible and near-visible spectral regions." The latter property of $\mathrm{BC}$ is illustrated in Fig. 1, which shows that the AAE is essentially unity. We note, however, that this might not be the case for collapsed BC aggregates [20, 25, 26] or internally mixed BC $[20,26]$, and should be viewed as a simplifying assumption only. E.g. Liu et al. [27] recently argued that the BC AAE generally is slightly lower than unity, based on advanced optical modeling and realistic particle geometries using fractal aggregates. However, we note that one can not use AAE alone to separate carbonaceous aerosols from dust, since AAE is also affected by particle size [26]. Consequently, the competing effects of large particle size driving AAE downward and hematite concentration driving AAE upward result in pure dust AAEs that can vary from less than 0 to greater than 3 [20].

Since BC never occurs in the atmosphere as pure carbonaceous matter [8], its optical properties are highly dependent on particle age, and on atmospheric conditions including the relative humidity and the availability of gaseous precursors for coating. This challenges both empirical definitions of $\mathrm{BC}$ for use in interpreting observations, and the ability of models to estimate global average absorption by BC. A 2006 review by Bond, Bergstrom [17] investigated the current theoretical understanding as well as observations, and proposed a representative MAC value of $7.5 \mathrm{~m}^{2} \mathrm{~g}^{-1}$ (at $550 \mathrm{~nm}$ ) for freshly generated BC. They suggested a range in MAC values from about $5 \mathrm{~m}^{2} \mathrm{~g}^{-1}$ for collapsed but uncoated BC, up to about $11 \mathrm{~m}^{2} \mathrm{~g}^{-1}$ for aged and coated BC (see Fig. 1). This range is consistent with more recent observations, in spite of a relatively large spread that reflects differences in measuring techniques, the type of airmass measured, mixing state, and proportion of BC in the aerosols [28-30]. As examples, Cui et al. [31] report average MAC values around $10 \mathrm{~m}^{2} \mathrm{~g}^{-1}$ (at $678 \mathrm{~nm}$ ) for a site in rural North China; Ram, Sarin [32] find values between 6 and $14 \mathrm{~m}^{2} \mathrm{~g}^{-1}$ (at $678 \mathrm{~nm}$ ) at different sites in India, whereas a lower value of around $6 \mathrm{~m}^{2} \mathrm{~g}^{-1}$ (at $522 \mathrm{~nm}$ ) is found for the Arctic [33]. Zanatta et al. [34] find an annual mean MAC value of $10 \mathrm{~m}^{2} \mathrm{~g}^{-1}$ (at $637 \mathrm{~nm}$ ) to be representative of the mixed boundary layer at European background sites.

\section{Ageing, Coating and Absorption Enhancement}

The range of reported MAC values as discussed above reflects that as $\mathrm{BC}$ mixes with other aerosol species, it can become coated, which enhances its absorptive properties, while the fresh fractal aggregates can collapse, which will reduce the enhancement. These processes are often collectively termed "BC ageing," even if sometimes only one of the two is implied. Laboratory experiments (e.g., [35-37]) find combined enhancement factors $\left(\mathrm{E}_{\mathrm{abs}}\right.$, defined as the ratio of absorption by aged $\mathrm{BC}$ relative to freshly emitted aerosol) of similar magnitude to those obtained in earlier measurements [17], but recent observational estimates show a large spread. Bond, Bergstrom [17] recommended a global enhancement factor of 1.5, a number which has been widely used in climate models. This means that assumed MAC values of fresh BC $7.5 \mathrm{~m}^{2} \mathrm{~g}^{-1}$ would correspond to MAC values of $11 \mathrm{~m}^{2} \mathrm{~g}^{-1}$ of the aged $B C$.

Several other studies have investigated $\mathrm{E}_{\mathrm{abs}}$ through observations, finding values raging from 1.0 to 3.0. See Supplementary Table 2 (ST2) for a (non-exhaustive) overview of recent observationally based estimates. Some of the differences between estimates of $\mathrm{E}_{\mathrm{abs}}$ can be attributed to the use of different instrumentation and methodologies (e.g., [38]), variations in the fraction of BC that is internally mixed (e.g., [25]) or dominance of different source contributions to the BC measured (e.g., [39]). A further source of confusion is the difference in baseline, from which the enhancement is calculated. Although the recommended $\mathrm{E}_{\mathrm{abs}}$ of 1.5 represents absorption enhancement from freshly emitted to fully aged $\mathrm{BC}$, some studies give $\mathrm{E}_{\mathrm{abs}}$ values for samples dominated by fresh local sources, relative to uncoated pure $\mathrm{BC}$ (e.g., [35, 40]). These $\mathrm{E}_{\mathrm{abs}}$

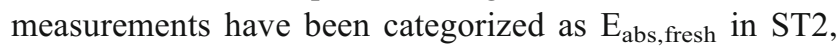
and typically show relatively small values. A few studies report enhancement between fresh and aged $\mathrm{BC}\left(\mathrm{E}_{\mathrm{abs}, \text { aged }}\right.$ in ST2), and these correspond reasonably to the value of 1.5. Yet other studies give the enhancement from pure uncoated BC to fully aged, producing in some cases very high $\mathrm{E}_{\mathrm{abs}}$ values (e.g., [31, 41]).

In climate models, $\mathrm{E}_{\mathrm{abs}}$ is calculated based on mixing state assumptions, or its value is simply set to a constant number (typically 1.5, as recommended in [17]). There is a large spread in the way models treat $\mathrm{BC}$, and many models even assume that all $\mathrm{BC}$ are externally mixed. This produces substantial differences in modeled MAC values. For instance, although Boucher et al. [42] use the indications from observations that MAC values should be somewhere in the vicinity of $10 \mathrm{~m}^{2} \mathrm{~g}^{-1}$ (at $550 \mathrm{~nm}$ ) on average, a multi-model study by Stjern et al. [16] shows a model mean MAC value of $6.3 \mathrm{~m}^{2} \mathrm{~g}^{-1}$ (at $550 \mathrm{~nm}$ ), but with individual model values ranging from 3 to $10 \mathrm{~m}^{2} \mathrm{~g}^{-1}$. These differences contribute to the large inter-model spread in $\mathrm{BC}$ absorption estimates.

New attempts to improve the parameterization of absorption enhancement in models are emerging in the literature. For instance, Fierce et al. [43] compare absorption enhancement in $\mathrm{BC}$ populations where the mass fraction of each aerosol component is assumed to be the same for all 
$\mathrm{BC}$ containing particles, to the enhancement found when using a model that resolves individual particles. They find that the latter approach yields an $\mathrm{E}_{\mathrm{abs}}$ of 1 to 1.5 at low relative humidity, consistent with ambient observations, whereas if a population-averaged composition is assumed across all BC-containing particles, absorption is strongly overestimated $\left(\mathrm{E}_{\mathrm{abs}}>2\right)$.

Liu et al. [44] use a generalized hybrid model approach for estimating scattering and absorption enhancements based on laboratory and atmospheric observations. They developed a method for determining when the $\mathrm{BC}$ is significantly enhanced by non-BC, based on the relative mass ratio of non- $\mathrm{BC}$ to $\mathrm{BC}$ in a single particle, which was already known to be important for $\mathrm{E}_{\mathrm{abs}}[20,26]$. Where the relative mass ratio is less than 1.5 (e.g., coatings typical of fresh traffic sources), BC is best represented as having little or no bulk absorption enhancement $\left(\mathrm{E}_{\mathrm{abs}}=1.0-1.4\right)$. For ratios greater than 3 (typical of aged biomass-burning emissions), $\mathrm{BC}$ is best described assuming optical lensing leading to an absorption enhancement $\left(\mathrm{E}_{\mathrm{abs}}>1.6\right)$. (We note that the term "lensing" is a geometric optics concept that has little meaning for subwavelength particle sizes, as is typical for combustion aerosols. However, we acknowledge that the term is widely used by the community and has a clear definition.) These developments are steps toward improving the representation of $\mathrm{BC}$ absorption in models.

\section{Residence Time, Vertical Profiles, and Emission Inventories}

Although absorption enhancements due to ageing is a key topic in recent BC literature, a number of other poorly constrained factors also contribute to the present spread in model results. As the absorption of an aerosol layer depends upon the albedo of the underlying surface, both the average residence time of atmospheric $\mathrm{BC}$ and its vertical concentration profile will influence absorption estimates and environmental impacts. For example, the HIPPO flight campaigns over the Pacific highlight a tendency in models to overestimate $\mathrm{BC}$ concentrations aloft [45], consistent with a general overestimate of residence time in the models [46]. Uncertainty in $\mathrm{BC}$ emission inventories is a further factor. Estimated global, annual mean emissions range from 4 to $14 \mathrm{Tg}_{\text {year }}{ }^{-1}[2,47$, 48]. Recently, Wang et al. [49] used a high resolution emission inventory over Asia, in combination with AERONET data, to further constrain BC AAOD through a Bayesian framework. They found significantly improved agreement when high resolution emissions were used, but also strong sensitivity to assumptions regarding $\mathrm{BC}$ ageing and transport. We discuss this study further below.

Recent developments in instrumentation are covered in subsequent sections on $\mathrm{BrC}$ and measurements.

\section{Brown Carbon}

$\mathrm{BrC}$ is a catch-all term for the absorbing components of organic carbon aerosols (OA), which unlike BC, absorbs strongly at short wavelengths, but less toward the nearinfrared part of the spectrum. Figure 1 shows the presently weak constraints on $\mathrm{BrC}$ optical properties, and the broad range of values that might actually apply under different circumstances. For a recent overview, see, e.g., Feng et al. [50], and references therein.

$\mathrm{BrC}$ is thought to be emitted primarily from biomass and biofuel burning [51-53], but it has also been seen in incomplete combustion of fossil fuels [54] and as a secondary organic aerosol [55-57].

A particular form of brown carbon that has received much recent attention is called tarballs; amorphous carbon spheres with mode diameters that range from about 100 to $300 \mathrm{~nm}$, but individual particle sizes ranging from $\sim 25 \mathrm{~nm}$ to over $1 \mu \mathrm{m}$ [58-60].

These near-perfect spheres are formed by gas-to-particle conversion during periods of high PM concentrations. They are larger than soot spherules, and lack the graphitic plate-like structure of soot. Tarballs are similar in composition to other organics $[61,62]$, but they are hydrophobic at relative humidities $(\mathrm{RH})$ less than about $83 \%$ [58]. They can become soluble and weakly hygroscopic when $\mathrm{RH}>83 \%$, but they do not deliquesce. Consequently, the spheres retain their shape and remain largely isolated, although aggregation is sometimes observed [58].

Tarballs occur in almost all smoke from biomass burning, independent of fuel type [60]. Biofuel burning can also create tarballs, and Alexander et al. [59] found them to be ubiquitous in the East Asian Pacific outflow. The proportion of tarball particles in smoke increases as the smoke ages, and can dominate the carbonaceous aerosol contribution within minutes; because it takes time for the gas-to-particle conversion process to form tarballs, and other aerosol quantities are simultaneously decreasing with age [60].

Tarballs are more strongly absorbing than other forms of brown carbon when measured in isolation. Alexander et al. [59] used electron energy-loss spectrums in transmission electron microscope images to estimate a mass absorption efficiency of 3.6 to $4.1 \mathrm{~m}^{2} \mathrm{~g}^{-1}$ at $550 \mathrm{~nm}$ for individual tarballs. This is significantly greater than the values that we present for brown carbon in Fig. 1, and significantly less than the value of $7.5 \mathrm{~m}^{2} \mathrm{~g}^{-1}$ recommended by Bond, Bergstrom [17] for soot carbon. Alexander et al. [59] determined an imaginary refractive index of $\mathrm{k}(550)=0.27$ for the 28 tarballs that they analyzed, which is also intermediate of humic-like brown carbon and soot carbon. Aerosol transport models at present generally do not include tarballs as a separate species from brown carbon, but that is appropriate given that tarballs, brown carbon, and organic carbon are not separatable by mass with current measurement techniques. 


\section{Distinguishing $\mathrm{BrC}$ from $\mathrm{BC}$}

Although the differences in spectral absorption between $\mathrm{BC}$ and $\mathrm{BrC}$ are profound, making it possible to distinguish the two observationally, considerable effort is still required to characterize the composition and microphysical properties of $\mathrm{BrC}$. This includes its absorption cross section and subsequent impact on global aerosol radiative forcing. Also, we note that modeling studies still sometimes use the term "black carbon" to include all non-dust absorbing aerosols, despite the vast differences in particle properties that are especially important for climate forcing calculations. Such unclear terminology can create significant issues when interpreting model results $[5,8,63]$.

Recent studies indicate a positive, global $\mathrm{BrC} \mathrm{RF}$ ranging from 0.1 to $0.6 \mathrm{~W} \mathrm{~m}^{-2}$, based on remote sensing $[49,64,65]$ and transport modeling [50, 52, 66-70]. The spread in results is likely affected by differing assumptions on $\mathrm{BrC}$ composition, optical properties, emissions, and transport. The microphysical properties of absorbing OA are also likely to be highly sensitive to particle formation processes, and to the details of their evolution in the atmosphere.

In an attempt to constrain the relative absorption contributions from $\mathrm{BrC}$ and $\mathrm{BC}$ from combustion emissions under controlled conditions, Pokhrel et al. [38] recently reported measurements for a wide range of biomass fuels. At $405 \mathrm{~nm}$, they find that $\mathrm{BrC}$ contributes of up to $92 \%$ of total absorption, but this fraction declined to $58 \%$ at $532 \mathrm{~nm}$. Critically, they also report that the $\mathrm{BrC}$ component varies by a factor of two between analysis assumptions commonly made in the literature. Absorption enhancement due to lensing from coating, as discussed for $\mathrm{BC}$ above, provides a further complication, as fresh $\mathrm{BC}$ and $\mathrm{BrC}$ may be coated with partly absorbing organics. For example, Saleh et al. [52] found a strongly nonlinear interplay between absorption and lensing for organic aerosols, and Pokhrel et al. [38] note that results on lensing are highly method and model dependent. Further, it has been suggested that $\mathrm{BrC}$ may lose its absorbing properties as it ages, on relatively short timescales of hours to days. Recently, instrumentation has become available allowing quantification of this effect under field conditions [71-73]. However, to our knowledge it is not presently implemented in global models, and may lead to significant revisions in the partitioning of total absorption between $\mathrm{BC}$ and $\mathrm{BrC}$ at short wavelengths.

\section{BrC Atmospheric Absorption}

Accounting for $\mathrm{BrC}$ absorption in the atmosphere has also seen rapid development, mainly employing spectrally resolved observations from AERONET. Initially, $\mathrm{AAE}=1$ was often assumed for $\mathrm{BC}$, and any nonlinearities subsequently ascribed to $\mathrm{BrC}$ (see, e.g., Olson et al. [54], and refs therein). Some studies refined this by grouping observational sites by region, and estimating optical parameters based on assumed single-source observations (e.g., [65, 74]). However, other authors have demonstrated that AAE does not contain enough information to unambiguously speciate the absorbing aerosols. See, in particular [26], and references therein. Briefly, $\mathrm{AAE}$ is affected by size; consequently the AAE of dust can hold a wide range of values (including less than 1), which in turn means that one can not use AAE alone to separate carbonaceous aerosols from dust.

Wang et al. [73] recently reported another approach that instead uses theoretical Mie calculations for BC, and no source assumptions. They find a global $\mathrm{BrC}$ absorption contribution of up to $40 \%$ of total carbonaceous aerosol absorption at $440 \mathrm{~nm}$, and a mass absorption coefficient for OA (here defined as the total group of organic aerosols in the GEOSChem model) that positively correlates with the BC-to-OA mass ratio. Detailed analysis at two urban sites revealed no significant ageing effect on the MAC value, whereas it was found to decrease with a half-life of 1 day at a biomass burning site. This indicates, consistent with several other studies, that $\mathrm{BrC}$ properties cannot be taken as globally uniform.

Recently, some regional constraints on $\mathrm{BrC}$ absorption and vertically resolved abundances have become available from aircraft observations [70, 75, 76]. Zhang et al. [70] show that over the continental USA in May to June 2012, BrC was prevalent throughout the troposphere. As the climate responses to absorbing aerosols change with altitude [77], the authors suggest that high altitude $\mathrm{BrC}$ lofted from biomass burning events should be further studied. This was for instance done by Peterson et al. [78], who developed a satellite-based inventory for pyrocumulonimbus clouds, which can elevate smoke particles into the upper troposphere and even the lower stratosphere. Promisingly, they find good correspondence between combined $\mathrm{BC}$ and $\mathrm{BrC}$ absorption determined from merging aircraft observations with radiative transfer calculations, and that obtained from remote sensing results from Ozone Monitoring Instrument (OMI) at two wavelengths (see below).

\section{$\mathrm{BrC}$ (and $\mathrm{BC}$ ) Instrumentation}

Recently, there has been great improvement in instrumentation for in situ observation, and separation, of atmospheric BC and BrC. Since the mid-2000s, many long-term monitoring sites and aircraft campaigns have used instruments such as the three-wavelength PSAP (Particle Soot Absorption Photometer) instrument, but due to its limited wavelength range $(467,530,660 \mathrm{~nm})$, spectral separation of $\mathrm{BC}$ and $\mathrm{BrC}$ is difficult. Seven-wavelength aethalometers, which are widely deployed at surface sites around the world, are better able to segregate $\mathrm{BC}$ and $\mathrm{BrC}[54,79-81]$ due to their extended spectral range (from ultraviolet to near-infrared), but still have issues because in real situations the AAE 
of $\mathrm{BC}$ varies with particle size and mixing state. A serious potential limitation of filter-based absorption instruments such as PSAPs and Aethalometers is that by collecting the aerosol on a filter the particles' physical and thus optical properties may be changed. Lack et al. [36] showed that PSAPs may overestimate absorption relative to photoacoustic instruments, depending on the amount of organic aerosol present. Filter-based instruments at long-term monitoring sites are typically operated to measure at low $\mathrm{RH}(<$ 40\%) (e.g., [82]); the drying required to achieve these RH levels can also affect the resulting absorption measurement, although the magnitude of this effect has not yet been quantified. The recent aircraft measurement papers cited above use a combination of Cavity Ring-Down (CRD) and Single Particle Soot Photometer (SP2) measurements. These instruments are much more sensitive to extinction or particle size, and can compute absorption from size distributions using assumptions about BC density and refractive index. However, they are difficult to operate unattended, precluding long-term, automated measurements. They also typically operate at non-ambient temperature and relative humidity conditions, as the sample air is brought into the aircraft and instrument. Upcoming campaigns will add photo-acoustic instruments, or the CAPS PM_ssa. Both the CAPS PM_ssa as well as some photo-acoustic instruments (e.g., the DMT PASS and PAX instruments;[83]) have the advantage of using the same sample volume to measure scattering and extinction to obtain SSA. This is a great improvement over previous in situ methods that required at least two instruments to determine SSA.

\section{Mineral Dust}

Wind-blown mineral dust is thought to be the most abundant atmospheric aerosol by mass, at least in most global aerosol models $[84,85]$, and influences both shortwave and longwave radiation. Given its high abundance, absorption from dust can dominate that of black and brown carbon in some regions and seasons [86]. However, even though there is significant variability in the regional composition and spectral absorption of mineral dust (e.g., [87, 88]), models typically use a single dust "type" and ignore regional dependencies of the complex refractive index. Absorption of aeolian dust is mainly caused by the minerals hematite and goethite, but the refractive indices of these minerals are not well known despite their impact on derived forcing [89]. There is significant variability in the published refractive indices of hematite [20] and we know of only two studies that presents goethite refractive indices [90, 91]. Given the prevalence of goethite [87, 92, 93] and the important role that this mineral plays in altering the AAE of dust aerosols, more work is needed to characterize the refractive index of goethite and incorporate regional refractive index variability associated with the hematite/goethite ratio into global models.

Figure 1 indicates the range of optical properties attributed to mineral dust. As with $\mathrm{BrC}$, it is usually taken to have an AAE significantly larger than 1 (see, e.g., [94]), although it can attain a very wide range of values depending on the actual ratio of minerals in the sample. Recently, Ridley et al. [95] used observations to constrain the dust AOD from the AeroCom Phase 2 model median of 0.023 ( 0.010 to 0.053 ) [96] to 0.030 ( 0.020 to 0.040 ), slightly increasing the AOD estimate and significantly reducing the spread. But many sources of model uncertainty and biases in dust absorption estimates remain, related to optical properties, in part because complex particle shapes are exceedingly difficult to model, but also because size distributions, shape, composition, and source terms are highly variable and poorly constrained by observations.

\section{Loading and Size Distributions}

Using satellite as well as ground-based measurements to constrain the global dust loading and its size distribution, Kok et al. [85] find that models overestimate emissions of fine dust and underestimate emissions of very coarse dust. Fine dust $(\mathrm{D} \leq 2 \mu \mathrm{m})$ with sizes on the order of solar wavelengths produce the largest shortwave scattering impact per unit aerosol mass (so generally cooling), whereas larger particles (diameter similar to wavelength of terrestrial radiation) have the largest longwave absorbing effect (so warming), based upon results from one global model [97]. Compared to fine dust, larger dust particles have stronger absorption in the solar spectrum as well [85]. Therefore, the size bias in dust emissions means that models will tend to underestimate the solar absorption by dust, as found from satellite/lidar measurements over the global oceans in Lacagnina et al. [98]. Another bias, limiting constraints on both extinction and absorption from dust, may arise from the tendency of models to approximate dust aerosols as being spherical in shape. Kok et al. [85] compare the dust extinction efficiency of spherical dust to that of tri-axial ellipsoids [99], and find the model assumption of sphericity to underestimate dust extinction efficiencies by as much as $20-60 \%$ for dust larger than $1 \mu \mathrm{m}$. Non-spherical scattering models that can accommodate distributions of complex particle shapes and orientations with reasonable computational speed have not been developed thus far. Spherical or ellipsoid models used as basis for radiative flux calculations do not seem to work well for radiance-based satellite retrievals of dust AOD, e.g., from Multi-angle Imaging SpectroRadiometer (MISR) [100]. Further, there is considerable variation and uncertainty in the absorption properties of dust from different sources [4], and observational constraints are difficult to apply to climate models due to a lack of adequate optical models, particularly single-scattering phase functions, for coarse-mode non- 
spherical dust of all types (e.g., [100]). Some models do use spheroids, showing that treatment of non-spherical dust is possible [101]. The lack of optical characterization of goethite in the literature is critical since this is the most abundant form of iron oxide in dust [102], and the major light absorber in the shortwave spectrum [103].

\section{Composition}

Di Biagio et al. [104] performed in situ measurements of a number of different soils from eight different regions, and found that although the fraction of scattering by the different dust types varied little, there was great variation in the light absorption from region to region and also for various sources within regions, with significant correlations to mineralogical composition. They suggest that using regionally dependent refractive indices rather than generic values can yield significant improvements in modeling of dust radiative effects. Similarly, e.g., Engelbrecht et al. [105] measured size distributions and the spectral SSA of surface dust from 18 countries (including China, USA, Australia, and multiple countries in Africa). Although they reported a range of SSA values, at $550 \mathrm{~nm}$ almost all dust samples had SSA $>0.95$.

\section{Multi-species, Model-Based Constraints}

Climate models try to combine the contributions to atmospheric absorption from several species into one estimate of the total global aerosol absorption, which can in turn be validated against observations. However, due in part to the issues raised above, inter-model differences in predicted AAOD are very large, even when using consistent emissions and nudged or prescribed meteorology. This issue was introduced in the Motivation section above, using the results from AeroCom Phase 2 [12]. Figure 2 further illustrates this, showing AAOD evaluated at $550 \mathrm{~nm}$ by the 16 global aerosol-climate models participating in that intercomparison. Some overall features are well captured by all models, including absorption by anthropogenic and biomass burning BC over Asia, Europe, Africa, and South America, dust from northern Africa and central Asia, and $\mathrm{BrC}$ from the major biomass burning regions for the few models that had included this component. (The yellow shaded parts of the figure show results from a single model as illustration.) The multi-model relative standard deviation (Fig. 2, upper right) rarely goes below 50\%. We note that it is lowest over high anthropogenic emission regions, where emissions were identical for all models. However, the relative standard deviation is very high over dust-

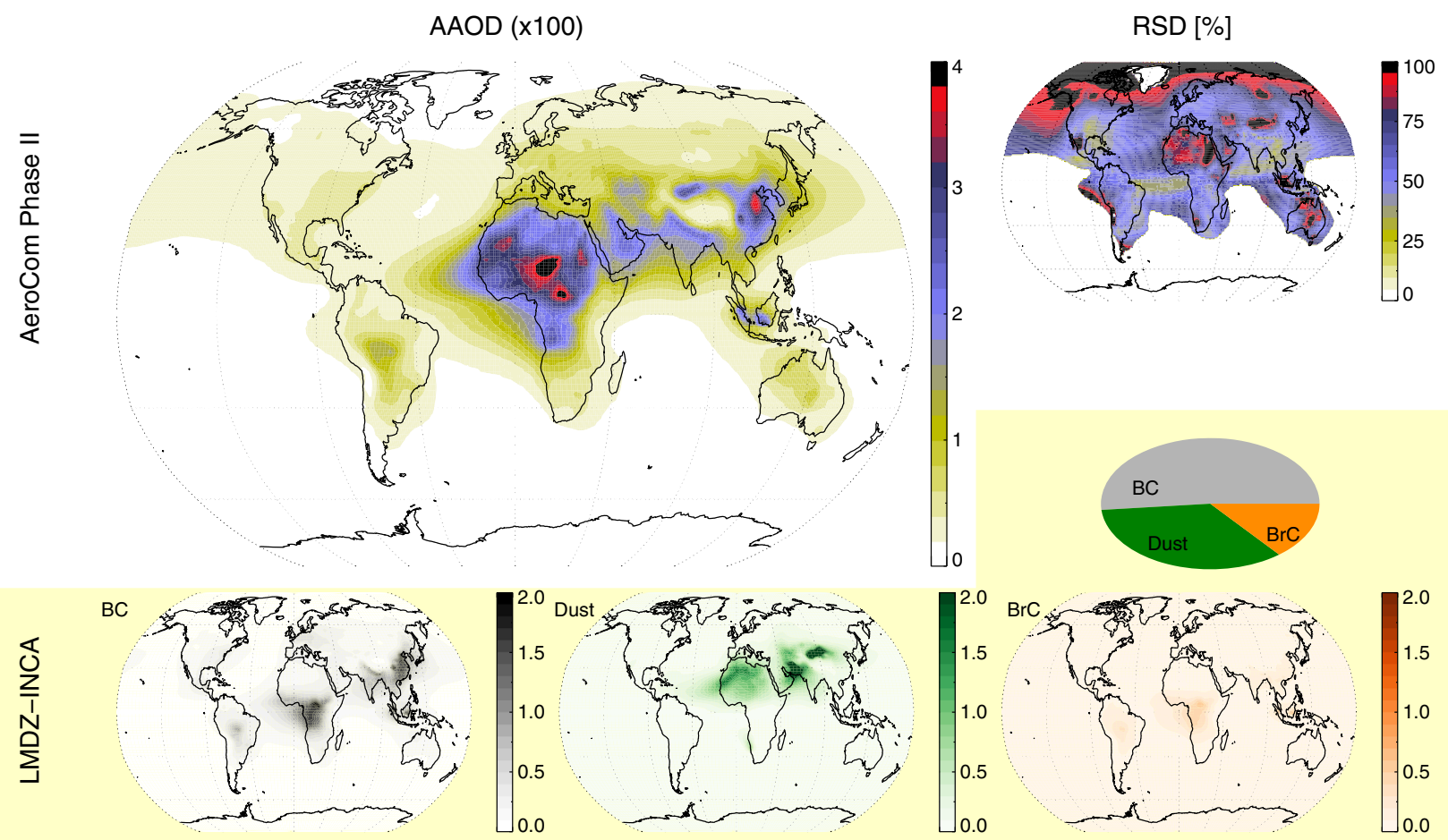

Fig. 2 Top: total, annual mean aerosol absorption optical depth (AAOD) from AeroCom Phase II (multi-model mean), and the relative standard deviation (RSD) between the 16 participating models. All models used consistent anthropogenic emissions from year 2000, and year 2006 meteorology. However, biomass burning emissions and dust source parameterization varied between models. RSD is only plotted for bins with AAOD > 0.0015. Bottom: simulated AAOD due to BC (gray), dust (green), and $\mathrm{BrC}$ (brown) in a single model (LMDZ-INCA). The pie chart indicates the relative contributions of each species to the global AAOD of that particular model 
emission regions, as dust emissions were not specified in the AeroCom exercise, but were estimated by each model based on meteorology for the same year. Also, for most models, a single dust "type" was assumed. One clear example of the implication of this assumption is the high absorption seen over the Bodélé depression (Chad, Central Africa), which is high in dust loading, but where the composition is mainly non-absorbing diatoms [106].

Most of the AeroCom models have undergone some degree of validation against observations, and the multi-model median holds up well when broadly evaluated against recent satellite remote sensing products (e.g., [98], see further discussion below). However, such an array of assumptions goes into these model calculations that it is difficult to assess the value of the (weak) multi-model, global-average constraint provided $(0.0042 \pm 0.0019)$. Consistency among models can arise due to common assumptions and/or tuning (see, e.g., [107]).

Another path towards model-based constraints is to combine information from multiple satellite retrievals with the full spatial coverage of a single numerical model, as done in the Monitoring Atmospheric Composition and Climate (MACC) project [108]. Here, model simulations are assimilated with MODIS retreivals of AOD $(550 \mathrm{~nm})$ and AERONET information on SSA, to derive AAOD. The use of assimilation combines global aerosol modeling and observations, and adds an additional layer of information relative to the earlier, purely observational, methods combining satellite and AERONET data $[109,110]$. MACC estimates a global, total AAOD of $0.008 \pm 0.002$ (i.e., almost twice that of AeroCom Phase II), mainly from anthropogenic sources (which include all biomass burning emissions) $(0.007 \pm 0.001)$, with the remainder being ascribed to mineral dust $(0.001 \pm 0.001)$.

\section{Observational Advances and Perspectives}

In the following, we discuss recent developments and known issues for ground and space-based remote sensing, and in situ measurements via regional flight campaigns and long-term surface monitoring sites. Presently, there is no practical way to provide global, self-consistent measurements from a single source that sufficiently constrains aerosol absorption for global modeling purposes. Still, satellite, aircraft, and surface station information can be used to validate or constrain global models, and therefore provide key, underlying constraints on climate scenarios and predictions.

Column aerosol absorption (i.e., AAOD) can, in principle, be retrieved from ground and space-based remote sensing platforms, though with uncertainties that limit their direct application for detailed climate forcing calculations (e.g., [111]). New instrumentation is in development that will provide a better understanding of the physical processes and hence the means to parameterize absorbing aerosol, but existing observational networks and datasets also provide crucial information. In situ observations can provide the most accurate observational constraints on aerosol spectral absorption and, depending on the instrument, such measurements likely meet the first-order requirements for climate forcing calculations $[9,63]$. In situ measurements from aircraft have limited spatial and temporal coverage, whereas in situ measurements from long-term surface sites can provide the temporal coverage and hence climatology, but again spatial coverage is limited, and transported aerosol might not be sampled adequately by in situ surface stations.

\section{Remote Sensing by Ground Stations}

Sun photometers at AERONET sites [112] provide AAOD retrievals at up to 600 locations around the globe, around $30 \%$ of which are in urban locations. As a long-running measurement network, AERONET provides invaluable climatological aerosol information; however, only a very few sites have operated consistently for the full range of about 20 years. Proper care must therefore be taken when selecting sites for climatological and/or trend absorption analyses. As with all passive ground-based technologies, AERONET can only observe total column properties. The AERONET algorithm also retrieves the aerosol complex refractive index, but it assumes it to be the same for all particle sizes in the atmospheric column [113]. Additionally, Level 2 absorption products such as AAOD require solar zenith angle $>50^{\circ}$ and $\mathrm{AOD}>0.4$ at $440 \mathrm{~nm}$. As AOD >0.4 is uncommon ([114], their Fig. 1; the global average AOD at $440 \mathrm{~nm}$ is not far above 0.14 ), this requirement means that Level 2 AAOD information is limited, and skewed towards conditions of high aerosol loading.

As the largest ground-based network capable of constraining column AAOD, AERONET has recently been used to provide constraints on models [115], to estimate $\mathrm{BC}$ emission inventories [116], and to scale estimates of radiative forcing [2, 49]. Russell et al. [117] recently showed how a cluster analysis of AERONET particle property retrievals can be combined with global-scale, multi-angle, multi-spectral, polarized measurements from the POLDER (Polarization and Directionality of the Earth's Reflectances) satellite instrument, to classify observations in terms of aerosol types, providing qualitative constraints on aerosol properties, including AAOD.

Schuster et al. [20] use the AERONET imaginary refractive index retrievals and published refractive indices to infer the relative abundance of $\mathrm{BC}, \mathrm{BrC}$, hematite, and goethite, using an end-member mixing approach. They utilized AERONET data at biomass burning sites and dust-dominated sites to illustrate that an imaginary index of $k=0.0042$ at the 675 1020-nm wavelengths robustly separates "pure" carbonaceous from "pure" dust aerosols. By further assuming that 
the spectral dependence of the AERONET imaginary refractive indices are associated with $\mathrm{BrC}$ or free iron, and that most $\mathrm{BrC}$ resides in the fine mode while most free iron resides in the coarse mode, they were able to retrieve regional and seasonal column loadings of absorbing aerosols that are consistent with expectations. They estimate an uncertainty of about $50 \%$ or better for BC and $100 \%$ or better for free iron.

A recurring question in recent literature has been what requirement should be set on total AOD for AERONET to give a good AAOD retrieval. As input to this, AERONET has been extensively compared with various types of airborne in situ measurements. These were recently summarized in Andrews et al. [118]. See Supplementary Fig. 2, left panel, adapted from data used in that study. The authors compare results from two US continental AERONET sites with in situ profiles from aircraft observations, with emphasis on low aerosol loading conditions. They confirm a previously reported tendency for AERONET inversions to overestimate absorption at low AOD values, suggesting a bias in either the retrievals or the in situ techniques. Previously, Kahn et al. [119], in a similar analysis comparing AERONET with MISR satellite data, attributed underestimates in AERONET SSA at least partly to methodological differences in measurements of AERONET directsun extinction and sky scan scattering quantities. These points further suggest caution in using AERONET to scale global model results, and brings into question the assumption that AERONET SSA values retrieved at high and low AOD conditions can be used to obtain AAOD at low AOD conditions (e.g., $[98,120])$. Thus AERONET SSA may not be representative of all loading conditions and/or seasons.

A further issue to note is vast differences in sampling size between most global models, at resolutions of $1^{\circ} \times 1^{\circ}$ or coarser, and AERONET point measurements. Using a high resolution emission inventory for Asia, a nested climate model and downscaling techniques, Wang et al. [49] recently explored the impact of model resolution on model-AERONET bias and, subsequently, radiative forcing of $\mathrm{BC}$. The analysis was made at $900 \mathrm{~nm}$, where $\mathrm{BrC}$ was assumed not to contribute to absorption. Contributions from dust were estimated by assuming a set of spectrally dependent optical parameters. They found significant reductions in bias when using highresolution modeling and emissions, and a reduction in predicted RF when using methods similar to previous studies. This is not surprising, as aerosol abundances are known to vary on small spatial scales compared to typical global-model resolution. It does, however, strongly indicate a need for higher resolution approaches to aerosol modeling if climate impacts are to be estimated with confidence.

\section{Remote Sensing by Satellites}

Several space-borne remote sensing instruments are currently capable of constraining aerosol absorption, at least qualitatively. Here, we discuss recent evaluations of MISR, OMI, and PARASOL retrievals.

The Earth Observing System (EOS) MISR flies aboard the NASA EOS's Terra satellite. It provides categorical constraints on particle size, shape, and absorption properties, distinguishing about 3-5 bins in particle size, 2-4 bins in SSA, and spherical vs. randomly oriented non-spherical particle shape under good but not necessarily ideal retrieval conditions [79, 121]. From multi-angle, multi-spectral remote sensing, aerosol type retrievals are much more sensitive to retrieval conditions than AOD. The MISR Standard aerosol retrieval algorithm runs automatically on the (approximately once-weekly) global dataset, with a climatology of 74 candidate aerosol mixture optical models, providing about a dozen aerosol-type distinctions where conditions warrant. The current MISR Standard algorithm (Version 22) tends to underestimate the occurrence of absorbing particles relative to ground (AERONET) measurements in situations where such particles are present, due in part to limitations in the algorithm particle climatology [122]. A more recent Research Algorithm, allowing many more aerosol component options, hundreds of candidate mixtures, empirical calibration refinement, and advanced surface modeling, can retrieve more information, particularly about particle absorption, and under a broader range of retrieval conditions, but only for individual case studies due to practical considerations [123, 124].

When many aerosol mixtures pass the MISR algorithm acceptance criteria, as frequently occurs when the AOD falls below about 0.15 or $0.2[66,111]$, there might be too little information in the observed MISR radiances to constrain aerosol type. Aerosol transport models, however, identify aerosol properties based on downwind advection from specified sources, so AOD is generally not a limiting factor. Li et al. [125] used model information to refine MISR aerosol microphysical property retrievals in conditions where many mixtures passed. They were able to trace remaining differences between the model, the constrained retrieval, and ground truth primarily to underestimations of AOD and AAE by the model in polluted regions, and missing aerosol types in the MISR product.

Another orbital platform frequently used to constrain aerosol light absorption is the OMI aboard the NASA EOS Aura satellite. Providing information mainly in the ultraviolet, it is able to retrieve AOD and AAOD at $388 \mathrm{~nm}$. The retrieval interprets aerosol absorption of upwelling, Rayleighscattered light from below and depends in part on having good constraints on the aerosol vertical distribution. The sensitivity of this approach improves for elevated vs. near-surface aerosol. Recently, OMI has been used to help validate the MERRA-2 (and the earlier MERRAero) re-analyses based on the GEOS-5 model [126, 127]. In general, the retrieval and reanalysis are in good agreement. However, a general overestimate by MERRA2 over land was observed. In a set of regional analyses, they focus on the Sahara (for dust), 
Africa and South America (for biomass burning aerosols), and Asia (anthropogenic mix). Dust AAOD reanalysis was improved by implementing recent updates to optical properties [128], whereas observed mismatches in the biomass burning regions were attributed to insufficient treatment of absorbing organic carbon (i.e., BrC). Over Asia, much of which is dominated by anthropogenic emissions, they point to emission inventories as a main source of uncertainty. However, possible impacts of aerosol absorption enhancement by rapid coating (the lensing effect mentioned previously) in high pollution environments [41] were not systematically discussed. In another recent study, Zhang et al. [129] use OMI AAOD to constrain $\mathrm{BC}$ abundances and emissions over Asia with the adjoint of the GEOS-Chem model. Using an optimization technique, they were able to significantly reduce model biases against AERONET and in situ ground truth at urban sites. Their results are similar to those of Wang et al. [49], indicating that greater regional specificity in emission inventories and additional constraints from space-based instruments can resolve a large fraction of the present uncertainty in $\mathrm{BC}$ emissions and concentrations.

The ESA PARASOL instrument measures polarization along with multi-angle, multi-spectral observations. The GRASP algorithm (Generalized Retrieval of Aerosol and Surface Properties) aims at gleaning information about absorbing aerosols from these data [130, 131]. Early work with this algorithm shows considerable promise in constraining particle size distributions and indices of refraction over a range of conditions. In particular, the added polarization information helps constrain both particle size and real refractive index, which contribute to the retrieval of particle absorption. As applied to the POLDER instruments aboard PARASOL, sensitivity to coarse-mode particles is limited by a lack of wavelengths longer than $910 \mathrm{~nm}$, and relatively coarse spatial resolution (6 km at nadir) complicates interpretation of retrievals where the surface or aerosol vary on kilometer scales. Lacagnina et al. [98] performed a thorough evaluation of PARASOL Standard Product AAOD versus AeroCom models, AERONET ground stations, and OMI, but only for ocean regions. They found that the ground and satellite remote sensing data compared well for AOD and AAOD (and SSA). The AeroCom models compared well against the remote sensing data for AOD, but the models produced much lower values for AAOD than the remote sensing data.

One critical issue for constraining the total climate effect of absorbing aerosols is their impact when located above clouds. In such cases, the high underlying albedo will enhance shortwave absorption, but both satellite and ground-based remote sensing have problems detecting the aerosol layer. Recently, improvements have been made by several satellite teams, leading to better constraints on above-cloud absorption. One method uses total and polarized radiances measured by POLDER, and has been shown to be efficient for detecting aerosols above clouds over the southeast Atlantic Ocean, Siberian biomass burning, and Saharan dust above clouds off the northwest coast of Africa [132]. For example, Peers et al. [133] recently compared the absorbing aerosols above clouds off the southwest coast of Southern Africa from the POLDER retrivals with several AeroCom models, and found that all models have lower AAOD above clouds compared to POLDER. The lower AAOD in models was primarily ascribed to lower AOD above clouds, but for those models showing reasonable AOD above clouds, the SSA was higher than in POLDER. Another method uses near-UV observations from OMI, simultaneously deriving the optical depth of the aerosol layer and the underlying cloud. This method has been tested with good results over the southern Atlantic Ocean [134]. Chand et al. [135] present a "color ratio" method, applied to CALIPSO data, to detect fine-mode, generally absorbing anthropogenic aerosol over cloud. Several groups expanded on this idea, using MODIS multi-spectral observations to simultaneously derive aerosol and underlying cloud optical thickness [136-139]. Yet another recent development is the use of geostationary satellite data from the Spinning Enhanced Visible and Infrared Imager (SEVIRI) in conjunction with A-Train [140]. Although no full constraint on abovecloud aerosol absorption yet exists, rapid progress is being made in this crucial area.

\section{In Situ Surface Stations}

Unlike remote-sensing retrievals, surface in situ measurements are not limited to daytime or cloud-free conditions, thus high temporal-resolution patterns can be studied. Additionally, measurements of absorption can be made at quite low near-surface loading conditions. Several networks are in operation, including IMPROVE, GAW, and the Environmental Protection Agency's STN (Speciation and Transport Network). One drawback of surface in situ networks is their limited spatial coverage - although the US and Europe support multiple surface networks making $\mathrm{BC}$ and/or aerosol absorption measurements with varying coverage density, other regions are much more sparsely represented.

Although measurements from surface in situ networks have been and continue to be used to evaluate model simulations of $\mathrm{BC}$ and dust (e.g., [101, 141-146]), one enduring issue for the comparison to be valid is ensuring that the measured quantity is the same as the modeled quantity (e.g., [9, 63]). The continuous nature of surface measurements means they can be used for trends studies (e.g., [101, 147]), climatologies in various regions (e.g., [34, 142]), and investigating inter-annual variability (e.g., [148]).

\section{In Situ Aircraft Measurements}

Fully constraining the vertical profiles of aerosol abundances, and hence absorption, should ideally be done in situ, using 
instruments in aircraft, balloons or, possibly, drones [149]. Recently, wider availability of high quality instrumentation such as the SP2 have led to greatly improved measurements of vertically resolved concentrations, both from campaigns targeted at specific processes, regions, and/or seasons (e.g., AFORCE [150], CLARIFY, SAMBBA [151]), and near-annualmean coverage in remote regions (HIPPO [45], ATom; https:// espo.nasa.gov/atom). However, flight information will always be limited in spatial and temporal coverage, relative to the wider view of satellites, and the continuous operation of some ground stations. Sampling issues therefore quickly arise when using aircraft data to constrain or validate models, as plumes or layers may be missed by the flights, while also being below the resolution of the models [152].

Above, we have discussed how dedicated flights were used to validate two particular AERONET sites [118], and how recent SP2 measurements indicate a significant loading of $\mathrm{BrC}$ at high altitudes over the continental USA [70]. Several groups also use flight information to constrain aerosol optical properties in a given regions. E.g. Lan et al. [40] find, from a flight campaign in an urban South China atmosphere, MAC of $\mathrm{BC}$ at $532 \mathrm{~nm}$ averaging $6.5 \mathrm{~m}^{2} \mathrm{~g}^{-1}$. A further use for aircraft measurements is to aid in constraining the radiative contribution of aerosol above clouds, as discussed above.

Even if it is sparse, the flight information available could be better utilized for constraining both models and retrievals. A first step is ensuring easy availability of consistent datasets. Here, recent initiatives such as the GASSP database [153] should be of great use in the future. Also, there is great potential in more systematic deployment of aircraft measurements, to constrain the average optical properties of aerosols in a given region and season. We discuss this further below.

As alluded to in the discussion of in situ BC instruments above, one issue that affects both surface and airborne in situ measurements of absorption is relating them to the ambient reality. In situ measurements have a tendency to change the sampling conditions (e.g., T, RH) from ambient. Some work has been done to couple SP2 with other systems to assess the hygroscopicity of absorbing aerosol (e.g., $[154,155])$ which may be useful for adjusting absorption measurements to ambient humidity conditions. Another issue is the possible volatilization of condensed material (thus possibly changing the lensing effect) during sampling, particularly if heating is used to bring the sample air down to a desired measurement humidity. Switching to diffusion driers or dry air dilution systems may minimize this potential volatilization effect for in situ measurements.

\section{A Roadmap Towards Improved Constraints on Aerosol Absorption}

In this review, we have defined a constraint as an agreement between observational and theoretical/model-based estimates of aerosol absorption, combined with an understanding of why the two are similar. At present, the field cannot provide such constraints. However, there is rapid progress on both fronts, and an encouraging increase in communication between the observational and modeling communities. In Table 1, we suggest a roadmap towards improved constraints, that includes model development, implementation of additional observational capabilities, and-crucially-increased adoption of common terms and definitions.

In summary, global and even regional-scale mapping of aerosol absorption remains challenging. No single source, models, in situ measurements, or satellite observations alone appears capable of providing the needed information to constrain absorption at the accuracy required for climate forcing applications, with adequate spatial and temporal coverage. Yet, taken together, this goal may still be achievable. Satellites offer frequent, global coverage and can map aerosol air mass types qualitatively, and with better constraints, under a wider range of observing conditions, when multi-angle, polarization data are acquired over a spectral range covering the near-UV to the near-IR. Details of particle absorption are best obtained from systematic, in situ measurements within the major aerosol air mass types. Although surface-based in situ measurements of aerosol absorption covering a range of air mass type exist due to the efforts of multiple monitoring networks, above-ground sampling is needed to adequately characterize transported aerosol types, and vertical profiles of in situ aerosol properties would better serve our ability to tie together satellite, remote sensing, and modeled absorption. Although such data are currently lacking in most cases, a climatological subset of key aerosol optical measurements has been acquired systematically within a single geographical region/ altitude [156, 157], and a concept for comprehensive, global measurements of this type has recently been presented [158]. Once an extensive database of detailed particle optical and microphysical properties is acquired in situ, including PDFs of particle hygroscopicity, mass extinction efficiency (needed to translate between aerosol optical depth retrieved from remote sensing and aerosol mass book keeping in models), and aerosol spectral absorption, these can be associated with the aerosol air mass types mapped from space [111]. Models can contribute to this overall picture by helping constrain the results where the satellite aerosol type retrievals are ambiguous (e.g., [125]), or are lacking, e.g., due to cloud cover, and the model can then in turn be constrained and/or validated by the aggregated observations.

Surface-based in situ measurements currently provide an underutilized dataset for evaluating and constraining modeled absorption in the boundary layer. If deployed at existing, longterm surface sites, the state of the art instruments mentioned above could go a long way towards resolving uncertainties in 
climatological physical properties. This, in turn, could aid in interpreting the existing long-term monitoring data (e.g., PSAP measurements) in light of the issues summarized in this review.

Further key areas of great present interest are constraints on the vertical distribution of absorbing aerosol, and the impacts of absorbing aerosol above cloud. Vertical distributions may be constrained in models through a combination of nearsource plume-heights, as determined, e.g., from multi-angle imaging, downwind layer profiles, retrieved, e.g., from space-based lidar, and the understanding that aerosol tends to concentrate in the boundary layer or in layers of relative stability in the free troposphere [159]. Such work has been suggested within the framework of the established AeroCom/ AeroSAT collaboration, and may provide very relevant constraints in the future. Aerosol above cloud are presently being evaluated both from models and remote sensing (the OMI and MODIS teams in particular), and is a focus of the current ORACLES field campaign, but is at present still a major source of uncertainty for the total radiative forcing exerted by aerosols.

In conclusion, although progress is rapid, there is still need for much additional work in characterizing aerosol light absorption in the atmosphere, and its effects on radiative forcing and - ultimately - the climate.

Funding Information BHS, CWS, and GM acknowledge funding through the RCN project AC/BC (240372). EA was supported by NOAA Climate Program Office's Atmospheric Chemistry, Carbon Cycle and Climate (AC4) program. MS acknowledges support from the EU ACTRIS-2 project (EU project No 654109). The work of R. Kahn is supported in part by NASA's Climate and Radiation Research and Analysis Program under H. Maring, and NASA's Atmospheric Composition Program under R. Eckman.

\section{Compliance with Ethical Standards}

Conflict of Interest On behalf of all authors, the corresponding author states that there is no conflict of interest.

Open Access This article is distributed under the terms of the Creative Commons Attribution 4.0 International License (http:// creativecommons.org/licenses/by/4.0/), which permits unrestricted use, distribution, and reproduction in any medium, provided you give appropriate credit to the original author(s) and the source, provide a link to the Creative Commons license, and indicate if changes were made.

\section{References}

1. Moosmüller H, Chakrabarty RK, Arnott WP. Aerosol light absorption and its measurement: a review. J Quant Spectrosc Radiat Transf. 2009;110(11):844-78. https://doi.org/10.1016/j. jqsit.2009.02.035.

2. Bond TC, Doherty SJ, Fahey DW, Forster PM, Berntsen T, DeAngelo BJ, et al. Bounding the role of black carbon in the climate system: a scientific assessment. J Geophys Res Atmos. 2013;118(11):5380-552. https://doi.org/10.1002/jgrd.50171.

3. Claquin T, Schulz M, Balkanski YJ. Modeling the mineralogy of atmospheric dust sources. J Geophys Res Atmos. 1999;104(D18): 22243-56. https://doi.org/10.1029/1999JD900416.

4. Sokolik IN, Toon OB. Incorporation of mineralogical composition into models of the radiative properties of mineral aerosol from UV to IR wavelengths. J Geophys Res Atmos. 1999;104(D8):942344. https://doi.org/10.1029/1998JD200048.

5. Andreae MO, Gelencsér A. Black carbon or brown carbon? The nature of light-absorbing carbonaceous aerosols. Atmos Chem Phys. 2006;6(10):3131-48. https://doi.org/10.5194/acp-6-31312006.

6. Kirchstetter TW, Novakov T, Hobbs PV. Evidence that the spectral dependence of light absorption by aerosols is affected by organic carbon. J Geophys Res Atmos. 2004;109(D21). https://doi.org/10. 1029/2004JD004999.

7. Bergstrom RW, Pilewskie P, Russell PB, Redemann J, Bond TC, Quinn PK, et al. Spectral absorption properties of atmospheric aerosols. Atmos Chem Phys. 2007;7(23):5937-43. https://doi. org/10.5194/acp-7-5937-2007.

8. Petzold A, Ogren JA, Fiebig M, Laj P, Li SM, Baltensperger U, et al. Recommendations for reporting "black carbon" measurements. Atmos Chem Phys. 2013;13(16):8365-79. https://doi.org/ 10.5194/acp-13-8365-2013.

9. Lack DA, Moosmüller H, McMeeking GR, Chakrabarty RK, Baumgardner D. Characterizing elemental, equivalent black, and refractory black carbon aerosol particles: a review of techniques, their limitations and uncertainties. Anal Bioanal Chem. 2014;406(1):99-122. https://doi.org/10.1007/s00216-013-7402-3.

10. Stier P, Seinfeld JH, Kinne S, Boucher O. Aerosol absorption and radiative forcing. Atmos Chem Phys. 2007;7(19):5237-61. https://doi.org/10.5194/acp-7-5237-2007.

11. Lamarque JF, Bond TC, Eyring V, Granier C, Heil A, Klimont Z, et al. Historical (1850-2000) gridded anthropogenic and biomass burning emissions of reactive gases and aerosols: methodology and application. Atmos Chem Phys. 2010;10(15):7017-39. https://doi.org/10.5194/acp-10-7017-2010.

12. Myhre G, Samset BH, Schulz M, Balkanski Y, Bauer S, Berntsen TK, et al. Radiative forcing of the direct aerosol effect from AeroCom Phase II simulations. Atmos Chem Phys. 2013;13(4): 1853-77. https://doi.org/10.5194/acp-13-1853-2013.

13. Hurrell JW, Holland MM, Gent PR, Ghan S, Kay JE, Kushner PJ, et al. The community earth system model: a framework for collaborative research. B Am Meteorol Soc. 2013;94(9):1339-60. https://doi.org/10.1175/BAMS-D-12-00121.1.

14. Forster PM, Richardson T, Maycock AC, Smith CJ, Samset BH, Myhre G, et al. Recommendations for diagnosing effective radiative forcing from climate models for CMIP6. J Geophys Res Atmos. 2016. https://doi.org/10.1002/2016JD025320.

15. Samset BH, Myhre G, Forster PM, Hodnebrog Ø, Andrews T, Faluvegi G, et al. Fast and slow precipitation responses to individual climate forcers: a PDRMIP multimodel study. Geophys Res Lett. 2016;43(6):2782-91. https://doi.org/10.1002/ 2016GL068064.

16. Stjern CW, Samset BH, Myhre G, Forster PM, Hodnebrog Ø, Andrews T, et al. Rapid adjustments cause weak surface temperature response to increased black carbon concentrations. J Geophys Res Atmos. 2017;122:11,462-11,481. https://doi.org/ 10.1002/2017JD027326.

17. Bond TC, Bergstrom RW. Light absorption by carbonaceous particles: an investigative review. Aerosol Sci Technol. 2006;40(1): 27-67. https://doi.org/10.1080/02786820500421521.

18. Chen Y, Bond TC. Light absorption by organic carbon from wood combustion. Atmos Chem Phys. 2010;10(4):1773-87. https://doi. org/10.5194/acp-10-1773-2010. 
19. Sun H, Biedermann L, Bond TC. Color of brown carbon: a model for ultraviolet and visible light absorption by organic carbon aerosol. Geophys Res Lett. 2007;34(17) https://doi.org/10.1029/ $2007 \mathrm{~g} 1029797$.

20. Schuster GL, Dubovik O, Arola A. Remote sensing of soot carbon-part 1: distinguishing different absorbing aerosol species. Atmos Chem Phys. 2016;16(3):1565-85. https://doi.org/10. 5194/acp-16-1565-2016.

21. Myhre G, Bellouin N, Berglen TF, Berntsen TK, Boucher O, Grini $\mathrm{A}$, et al. Comparison of the radiative properties and direct radiative effect of aerosols from a global aerosol model and remote sensing data over ocean. Tellus B. 2007;59(1):115-29. https://doi.org/10. 1111/j.1600-0889.2006.00226.x.

22. Osborne SR, Johnson BT, Haywood JM, Baran AJ, Harrison MAJ, McConnell CL. Physical and optical properties of mineral dust aerosol during the dust and biomass-burning experiment. J Geophys Res. 2008;113(D23). https://doi.org/10.1029/ $2007 \mathrm{jd} 009551$.

23. Andersson A. A model for the spectral dependence of aerosol sunlight absorption. ACS Earth Space Chem. 2017;1(9):533-39. https://doi.org/10.1021/acsearthspacechem.7b00066.

24. Mikhailov EF, Vlasenko SS, Podgorny IA, Ramanathan V, Corrigan CE. Optical properties of soot-water drop agglomerates: an experimental study. J Geophys Res Atmos. 2006;111(D7). https://doi.org/10.1029/2005JD006389.

25. Schwarz JP, Gao RS, Spackman JR, Watts LA, Thomson DS, Fahey DW, et al. Measurement of the mixing state, mass, and optical size of individual black carbon particles in urban and biomass burning emissions. Geophys Res Lett. 2008;35(13). https:// doi.org/10.1029/2008GL033968.

26. Schuster GL, Dubovik O, Arola A, Eck TF, Holben BN. Remote sensing of soot carbon-part 2: understanding the absorption Ångström exponent. Atmos Chem Phys. 2016;16(3):1587-602. https://doi.org/10.5194/acp-16-1587-2016.

27. Liu C, Chul CE, Yin Y. The absorption Ångström exponent of black carbon: from numerical aspects. Atmos Chem Phys Discuss. 2017:1-30. https://doi.org/10.5194/acp-2017-836.

28. Neusüß C, Gnauk T, Plewka A, Herrmann H, Quinn PK. Carbonaceous aerosol over the Indian Ocean: OC/EC fractions and selected specifications from size-segregated onboard samples. J Geophys Res Atmos. 2002;107(D19). https://doi.org/10.1029/ 2001JD000327

29. Schuster GL, Dubovik O, Holben BN, Clothiaux EE. Inferring black carbon content and specific absorption from Aerosol Robotic Network (AERONET) aerosol retrievals. J Geophys Res Atmos. 2005;110(D10):n/a-n/a) https://doi.org/10.1029/ 2004JD004548.

30. Petzold A, Kopp C, Niessner R. The dependence of the specific attenuation cross-section on black carbon mass fraction and particle size. Atmos Environ. 1997;31(5):661-72. https://doi.org/10. 1016/s1352-2310(96)00245-2.

31. Cui X, Wang X, Yang L, Chen B, Chen J, Andersson A, et al. Radiative absorption enhancement from coatings on black carbon aerosols. Sci Total Environ. 2016;551:51-6. https://doi.org/10. 1016/j.scitotenv.2016.02.026.

32. Ram K, Sarin MM. Absorption coefficient and site-specific mass absorption efficiency of elemental carbon in aerosols over urban, rural, and high-altitude sites in India. Environ Sci Technol. 2009;43(21):8233-9. https://doi.org/10.1021/es9011542.

33. Yttri KE, Lund Myhre C, Eckhardt S, Fiebig M, Dye C, Hirdman $\mathrm{D}$, et al. Quantifying black carbon from biomass burning by means of levoglucosan - a one-year time series at the Arctic observatory Zeppelin. Atmos Chem Phys. 2014;14(12):6427-42. https://doi. org/10.5194/acp-14-6427-2014.

34. Zanatta M, Gysel M, Bukowiecki N, Müller T, Weingartner E, Areskoug $\mathrm{H}$, et al. A European aerosol phenomenology-5: climatology of black carbon optical properties at 9 regional background sites across Europe. Atmos Environ. 2016;145:346-64. https://doi.org/10.1016/j.atmosenv.2016.09.035.

35. Cappa CD, Onasch TB, Massoli P, Worsnop DR, Bates TS, Cross ES, et al. Radiative absorption enhancements due to the mixing state of atmospheric black carbon. Science. 2012;337(6098): 1078-81. https://doi.org/10.1126/science.1223447.

36. Lack DA, Cappa CD, Cross ES, Massoli P, Ahern AT, Davidovits $\mathrm{P}$, et al. Absorption enhancement of coated absorbing aerosols: validation of the photo-acoustic technique for measuring the enhancement. Aerosol Sci Technol. 2009;43(10):1006-12. https:// doi.org/10.1080/02786820903117932.

37. Zhang R, Khalizov AF, Pagels J, Zhang D, Xue H, McMurry PH. Variability in morphology, hygroscopicity, and optical properties of soot aerosols during atmospheric processing. Proc Natl Acad Sci. 2008;105(30):10291-6. https://doi.org/10.1073/pnas. 0804860105 .

38. Pokhrel RP, Beamesderfer ER, Wagner NL, Langridge JM, Lack DA, Jayarathne T, et al. Relative importance of black carbon, brown carbon, and absorption enhancement from clear coatings in biomass burning emissions. Atmos Chem Phys. 2017;17(8): 5063-78. https://doi.org/10.5194/acp-17-5063-2017.

39. Nakayama T, Ikeda Y, Sawada Y, Setoguchi Y, Ogawa S, Kawana $\mathrm{K}$, et al. Properties of light-absorbing aerosols in the Nagoya urban area, Japan, in August 2011 and January 2012: contributions of brown carbon and lensing effect. J Geophys Res Atmos. 2014;119(22):12,721-712,739. https://doi.org/10.1002/ 2014JD021744.

40. Lan Z-J, Huang X-F, Yu K-Y, Sun T-L, Zeng L-W, Hu M. Light absorption of black carbon aerosol and its enhancement by mixing state in an urban atmosphere in South China. Atmos Environ. 2013;69:118-23. https://doi.org/10.1016/j.atmosenv.2012.12. 009.

41. Peng J, Hu M, Guo S, Du Z, Zheng J, Shang D, et al. Markedly enhanced absorption and direct radiative forcing of black carbon under polluted urban environments. Proc Natl Acad Sci. 2016;113(16):4266-71. https://doi.org/10.1073/pnas. 1602310113.

42. Boucher O, Balkanski Y, Hodnebrog Ø, Myhre CL, Myhre G, Quaas J, et al. Jury is still out on the radiative forcing by black carbon. Proc Natl Acad Sci. 2016;113(35):E5092-3. https://doi. org/10.1073/pnas.1607005113.

43. Fierce L, Bond TC, Bauer SE, Mena F, Riemer N. Black carbon absorption at the global scale is affected by particle-scale diversity in composition. Nat Commun. 2016;7:12361. https://doi.org/10. 1038/ncomms 12361.

44. Liu D, Whitehead J, Alfarra MR, Reyes-Villegas E, Spracklen DV, Reddington CL, et al. Black-carbon absorption enhancement in the atmosphere determined by particle mixing state. Nat Geosci. 2017;10(3):184-8. https://doi.org/10.1038/ngeo2901.

45. Schwarz JP, Samset BH, Perring AE, Spackman JR, Gao RS, Stier P, et al. Global-scale seasonally resolved black carbon vertical profiles over the Pacific. Geophys Res Lett. 2013;40(20):55427. https://doi.org/10.1002/2013GL057775.

46. Samset BH, Myhre G, Herber A, Kondo Y, Li SM, Moteki N, et al. Modelled black carbon radiative forcing and atmospheric lifetime in AeroCom Phase II constrained by aircraft observations. Atmos Chem Phys. 2014;14(22):12465-77. https://doi.org/10.5194/acp14-12465-2014.

47. Bond TC, Bhardwaj E, Dong R, Jogani R, Jung S, Roden C, et al. Historical emissions of black and organic carbon aerosol from energy-related combustion, 1850-2000. Global Biogeochem Cycles. 2007;21(2). https://doi.org/10.1029/2006GB002840.

48. Cohen JB, Wang C. Estimating global black carbon emissions using a top-down Kalman Filter approach. J Geophys Res 
Atmos. 2014;119(1):307-23. https://doi.org/10.1002/ 2013JD019912.

49. Wang R, Balkanski Y, Boucher O, Ciais P, Schuster GL, Chevallier F, et al. Estimation of global black carbon direct radiative forcing and its uncertainty constrained by observations. $\mathrm{J}$ Geophys Res Atmos. 2016;121(10):5948-71. https://doi.org/10. 1002/2015JD024326.

50. Feng Y, Ramanathan V, Kotamarthi VR. Brown carbon: a significant atmospheric absorber of solar radiation? Atmos Chem Phys. 2013;13(17):8607-21. https://doi.org/10.5194/acp-13-86072013.

51. Lack DA, Langridge JM, Bahreini R, Cappa CD, Middlebrook AM, Schwarz JP. Brown carbon and internal mixing in biomass burning particles. Proc Natl Acad Sci. 2012;109(37):14802-7. https://doi.org/10.1073/pnas.1206575109.

52. Saleh R, Marks M, Heo J, Adams PJ, Donahue NM, Robinson AL. Contribution of brown carbon and lensing to the direct radiative effect of carbonaceous aerosols from biomass and biofuel burning emissions. J Geophys Res Atmos. 2015;120(19). https:// doi.org/10.1002/2015JD023697.

53. Washenfelder RA, Attwood AR, Brock CA, Guo H, Xu L, Weber $\mathrm{RJ}$, et al. Biomass burning dominates brown carbon absorption in the rural southeastern United States. Geophys Res Lett. 2015;42(2):653-64. https://doi.org/10.1002/2014GL062444.

54. Olson MR, Victoria Garcia M, Robinson MA, Van Rooy P, Dietenberger MA, Bergin M, et al. Investigation of black and brown carbon multiple-wavelength-dependent light absorption from biomass and fossil fuel combustion source emissions. J Geophys Res Atmos. 2015;120(13):6682-97. https://doi.org/10. 1002/2014JD022970.

55. Lin G, Penner JE, Flanner MG, Sillman S, Xu L, Zhou C. Radiative forcing of organic aerosol in the atmosphere and on snow: effects of SOA and brown carbon. J Geophys Res Atmos. 2014;119(12):7453-76. https://doi.org/10.1002/2013jd021186.

56. Lin P, Liu J, Shilling JE, Kathmann SM, Laskin J, Laskin A. Molecular characterization of brown carbon $(\mathrm{BrC})$ chromophores in secondary organic aerosol generated from photo-oxidation of toluene. Phys Chem Chem Phys. 2015;17(36):23312-25. https:// doi.org/10.1039/c5cp02563j.

57. Zhang X, Lin YH, Surratt JD, Weber RJ. Sources, composition and absorption Angstrom exponent of light-absorbing organic components in aerosol extracts from the Los Angeles Basin. Environ Sci Technol. 2013;47(8):3685-93. https://doi.org/10. 1021/es305047b.

58. Hand JL, Malm WC, Laskin A, Day D, Lee T, Wang C, et al. Optical, physical, and chemical properties of tar balls observed during the Yosemite Aerosol Characterization Study. J Geophys Res. 2005;110(D21) https://doi.org/10.1029/2004jd005728.

59. Alexander DT, Crozier PA, Anderson JR. Brown carbon spheres in East Asian outflow and their optical properties. Science. 2008;321(5890):833-6. https://doi.org/10.1126/science.1155296.

60. Adachi K, Buseck PR. Atmospheric tar balls from biomass burning in Mexico. J Geophys Res. 2011;116(D5) https://doi.org/10. 1029/2010jd015102.

61. Pósfai M, Simonics R, Li J, Hobbs PV, Buseck PR. Individual aerosol particles from biomass burning in southern Africa: 1 . Compositions and size distributions of carbonaceous particles. J Geophys Res Atmos. 2003;108(D13). https://doi.org/10.1029/ 2002jd002291.

62. Semeniuk TA, Wise ME, Martin ST, Russell LM, Buseck PR. Hygroscopic behavior of aerosol particles from biomass fires using environmental transmission electron microscopy. J Atmos Chem. 2006;56(3):259-73. https://doi.org/10.1007/s10874-0069055-5.

63. Vignati E, Karl M, Krol M, Wilson J, Stier P, Cavalli F. Sources of uncertainties in modelling black carbon at the global scale. Atmos
Chem Phys. 2010;10(6):2595-611. https://doi.org/10.5194/acp10-2595-2010.

64. Arola A, Schuster G, Myhre G, Kazadzis S, Dey S, Tripathi SN. Inferring absorbing organic carbon content from AERONET data. Atmos Chem Phys. 2011;11(1):215-25. https://doi.org/10.5194/ acp-11-215-2011.

65. Chung CE, Ramanathan V, Decremer D. Observationally constrained estimates of carbonaceous aerosol radiative forcing. Proc Natl Acad Sci. 2012;109(29):11624-9. https://doi.org/10. 1073/pnas.1203707109.

66. Bellouin N, Rae J, Jones A, Johnson C, Haywood J, Boucher O. Aerosol forcing in the Climate Model Intercomparison Project (CMIP5) simulations by HadGEM2-ES and the role of ammonium nitrate. J Geophys Res Atmos. 2011;116(D20):n/a-n/a) https:// doi.org/10.1029/2011JD016074.

67. Jo DS, Park RJ, Lee S, Kim SW, Zhang X. A global simulation of brown carbon: implications for photochemistry and direct radiative effect. Atmos Chem Phys. 2016;16(5):3413-32. https://doi. org/10.5194/acp-16-3413-2016.

68. Wang Q, Jacob DJ, Spackman JR, Perring AE, Schwarz JP, Moteki N, et al. Global budget and radiative forcing of black carbon aerosol: constraints from pole-to-pole (HIPPO) observations across the Pacific. J Geophys Res Atmos. 2014;119(1):195206. https://doi.org/10.1002/2013JD020824.

69. Yan C, Zheng M, Bosch C, Andersson A, Desyaterik Y, Sullivan $\mathrm{AP}$, et al. Important fossil source contribution to brown carbon in Beijing during winter. Sci Rep. 2017;7:43182. https://doi.org/10. 1038/srep43182.

70. Zhang Y, Forrister H, Liu J, Dibb J, Anderson B, Schwarz JP, et al. Top-of-atmosphere radiative forcing affected by brown carbon in the upper troposphere. Nat Geosci. 2017;10(7):486-9. https://doi. org/10.1038/ngeo2960. http://www.nature.com/ngeo/journal/v10/ n7/abs/ngeo2960.html\#supplementary-information

71. Forrister H, Liu J, Scheuer E, Dibb J, Ziemba L, Thornhill KL, et al. Evolution of brown carbon in wildfire plumes. Geophys Res Lett. 2015;42(11):4623-30. https://doi.org/10.1002/ 2015GL063897.

72. Lee HJ, Aiona PK, Laskin A, Laskin J, Nizkorodov SA. Effect of solar radiation on the optical properties and molecular composition of laboratory proxies of atmospheric brown carbon. Environ Sci Technol. 2014;48(17):10217-26. https://doi.org/10.1021/es502515r.

73. Wang Q, Saturno J, Chi X, Walter D, Lavric JV, Moran-Zuloaga D, et al. Modeling investigation of light-absorbing aerosols in the Amazon Basin during the wet season. Atmos Chem Phys. 2016;16(22):14775-94. https://doi.org/10.5194/acp-16-14775-2016.

74. Bahadur R, Praveen PS, Xu Y, Ramanathan V. Solar absorption by elemental and brown carbon determined from spectral observations. Proc Natl Acad Sci. 2012;109(43):17366-71. https://doi. org/10.1073/pnas.1205910109.

75. Liu J, Scheuer E, Dibb J, Ziemba LD, Thornhill KL, Anderson $\mathrm{BE}$, et al. Brown carbon in the continental troposphere. Geophys Res Lett. 2014;41(6):2191-5. https://doi.org/10.1002/ $2013 \mathrm{~g} 1058976$.

76. Wang X, Heald CL, Liu J, Weber RJ, Campuzano-Jost P, Jimenez JL, Schwarz JP, Perring AE. Exploring the observational constraints on the simulation of brown carbon. Atmos Chem Phys. 2018;18:635-53. https://doi.org/10.5194/acp-18-635-2018.

77. Samset BH, Myhre G. Climate response to externally mixed black carbon as a function of altitude. J Geophys Res Atmos. 2015;120(7):2014JD022849. https://doi.org/10.1002/ 2014JD022849.

78. Peterson DA, Fromm MD, Solbrig JE, Hyer EJ, Surratt ML, Campbell JR. Detection and inventory of intense pyroconvection in Western North America using GOES-15 daytime infrared data. J Appl Meteorol Climatol. 2017;56(2):471-93. https://doi.org/10. 1175/jamc-d-16-0226.1. 
79. Devi JJ, Bergin MH, McKenzie M, Schauer JJ, Weber RJ. Contribution of particulate brown carbon to light absorption in the rural and urban Southeast US. Atmos Environ. 2016;136: 95-104. https://doi.org/10.1016/j.atmosenv.2016.04.011.

80. Wang X, Heald CL, Sedlacek AJ, de Sá SS, Martin ST, Alexander ML, et al. Deriving brown carbon from multiwavelength absorption measurements: method and application to AERONET and Aethalometer observations. Atmos Chem Phys. 2016;16(19): 12733-52. https://doi.org/10.5194/acp-16-12733-2016.

81. Yang M, Howell SG, Zhuang J, Huebert BJ. Attribution of aerosol light absorption to black carbon, brown carbon, and dust in China-interpretations of atmospheric measurements during EAST-AIRE. Atmos Chem Phys. 2009;9(6):2035-50. https:// doi.org/10.5194/acp-9-2035-2009.

82. WMO. WMO/GAW Aerosol Measurement Procedures, Guidelines and Recommendations, 2nd Edition. 2016.

83. Lewis K, Arnott WP, Moosmüller H, Wold CE. Strong spectral variation of biomass smoke light absorption and single scattering albedo observed with a novel dual-wavelength photoacoustic instrument. J Geophys Res Atmos. 2008;113(D16). https://doi.org/ 10.1029/2007JD009699.

84. Textor C, Schulz M, Guibert S, Kinne S, Balkanski Y, Bauer S, et al. Analysis and quantification of the diversities of aerosol life cycles within AeroCom. Atmos Chem Phys. 2006;6:1777-813.

85. Kok JF, Ridley DA, Zhou Q, Miller RL, Zhao C, Heald CL, et al. Smaller desert dust cooling effect estimated from analysis of dust size and abundance. Nature Geosci. 2017;10(4):274-8. https:// doi.org/10.1038/ngeo2912.

86. Caponi L, Formenti P, Massabó D, Di Biagio C, Cazaunau M, Pangui E, et al. Spectral- and size-resolved mass absorption efficiency of mineral dust aerosols in the shortwave spectrum: a simulation chamber study. Atmos Chem Phys. 2017;17(11):7175-91. https://doi.org/10.5194/acp-17-7175-2017.

87. Formenti P, Caquineau S, Chevaillier S, Klaver A, Desboeufs K, Rajot JL, et al. Dominance of goethite over hematite in iron oxides of mineral dust from Western Africa: quantitative partitioning by X-ray absorption spectroscopy. J Geophys Res Atmos. 2014;119(22):12,740-712,754. https://doi.org/10.1002/ 2014JD021668.

88. Formenti P, Schütz L, Balkanski Y, Desboeufs K, Ebert M, Kandler K, et al. Recent progress in understanding physical and chemical properties of African and Asian mineral dust. Atmos Chem Phys. 2011;11(16):8231-56. https://doi.org/10.5194/acp11-8231-2011.

89. Balkanski Y, Schulz M, Claquin T, Guibert S. Reevaluation of mineral aerosol radiative forcings suggests a better agreement with satellite and AERONET data. Atmos Chem Phys. 2007;7(1):8195. https://doi.org/10.5194/acp-7-81-2007.

90. Bedidi A, Cervelle B. Light scattering by spherical particles with hematite and goethitelike optical properties: effect of water impregnation. J Geophys Res Solid Earth. 1993;98(B7):11941-52. https://doi.org/10.1029/93JB00188.

91. Hunt JM, Wisherd MP, Bonham LC. Infrared absorption spectra of minerals and other inorganic compounds. Anal Chem. 1950;22(12):1478-97. https://doi.org/10.1021/ac60048a006.

92. Fontes MPF, Carvalho IA. Color attributes and mineralogical characteristics, evaluated by radiometry, of highly weathered tropical soils. Soil Sci Soc Am J. 2005;69(4):1162-72. https://doi.org/ 10.2136/sssaj2003.0312.

93. Shi Z, Krom MD, Jickells TD, Bonneville S, Carslaw KS, Mihalopoulos N, et al. Impacts on iron solubility in the mineral dust by processes in the source region and the atmosphere: a review. Aeolian Res. 2012;5(Supplement C):21-42. https://doi. org/10.1016/j.aeolia.2012.03.001.

94. Linke C, Möhler O, Veres A, Mohácsi Á, Bozóki Z, Szabó G, et al. Optical properties and mineralogical composition of different
Saharan mineral dust samples: a laboratory study. Atmos Chem Phys. 2006;6(11):3315-23. https://doi.org/10.5194/acp-6-33152006.

95. Ridley DA, Heald CL, Kok JF, Zhao C. An observationally constrained estimate of global dust aerosol optical depth. Atmos Chem Phys. 2016;16(23):15097-117. https://doi.org/10.5194/ acp-16-15097-2016.

96. Huneeus N, Schulz M, Balkanski Y, Griesfeller J, Prospero J, Kinne S, et al. Global dust model intercomparison in AeroCom phase I. Atmos Chem Phys. 2011;11(15):7781-816. https://doi. org/10.5194/acp-11-7781-2011.

97. Miller RL, Cakmur RV, Perlwitz J, Geogdzhayev IV, Ginoux P, Koch D, et al. Mineral dust aerosols in the NASA Goddard Institute for Space Sciences ModelE atmospheric general circulation model. J Geophys Res Atmos. 2006;111(D6). https://doi.org/ 10.1029/2005JD005796.

98. Lacagnina C, Hasekamp OP, Bian H, Curci G, Myhre G, van Noije T, et al. Aerosol single-scattering albedo over the global oceans: Comparing PARASOL retrievals with AERONET, OMI, and AeroCom models estimates. J Geophys Res Atmos. 2015;120(18):9814-36. https://doi.org/10.1002/2015JD023501.

99. Meng Z, Yang P, Kattawar GW, Bi L, Liou KN, Laszlo I. Singlescattering properties of tri-axial ellipsoidal mineral dust aerosols: a database for application to radiative transfer calculations. J Aerosol Sci. 2010;41(5):501-12. https://doi.org/10.1016/j. jaerosci.2010.02.008.

100. Kalashnikova OV, Kahn R. Ability of multiangle remote sensing observations to identify and distinguish mineral dust types: 2 . Sensitivity over dark water. J Geophys Res Atmos. 2006;111(D11):n/a-n/a) https://doi.org/10.1029/2005JD006756.

101. Chin M, Diehl T, Tan Q, Prospero JM, Kahn RA, Remer LA, et al. Multi-decadal aerosol variations from 1980 to 2009: a perspective from observations and a global model. Atmos Chem Phys. 2014;14(7):3657-90. https://doi.org/10.5194/acp-14-3657-2014.

102. Lafon S, Sokolik IN, Rajot JL, Caquineau S, Gaudichet A. Characterization of iron oxides in mineral dust aerosols: implications for light absorption. J Geophys Res Atmos. 2006;111(D21). https://doi.org/10.1029/2005JD007016.

103. Zhang XL, Wu GJ, Zhang CL, Xu TL, Zhou QQ. What is the real role of iron oxides in the optical properties of dust aerosols? Atmos Chem Phys. 2015;15(21):12159-77. https://doi.org/10. 5194/acp-15-12159-2015.

104. Di Biagio C, Formenti P, Balkanski Y, Caponi L, Cazaunau M, Pangui E, et al. Global scale variability of the mineral dust longwave refractive index: a new dataset of in situ measurements for climate modeling and remote sensing. Atmos Chem Phys. 2017;17(3):1901-29. https://doi.org/10.5194/acp-17-1901-2017.

105. Engelbrecht JP, Moosmüller H, Pincock S, Jayanty RKM, Lersch T, Casuccio G. Technical note: mineralogical, chemical, morphological, and optical interrelationships of mineral dust re-suspensions. Atmos Chem Phys. 2016;16(17):10809-30. https://doi.org/ 10.5194/acp-16-10809-2016.

106. Todd MC, Washington R, Martins JV, Dubovik O, Lizcano G, M'Bainayel S, et al. Mineral dust emission from the Bodélé Depression, northern Chad, during BoDEx 2005. J Geophys Res. 2007;112(D6) https://doi.org/10.1029/2006jd007170.

107. Samset BH, Myhre G, Schulz M. Upward adjustment needed for aerosol radiative forcing uncertainty. Nat Clim Chang. 2014;4(4): 230-2. https://doi.org/10.1038/nclimate2170.

108. Bellouin N, Quaas J, Morcrette JJ, Boucher O. Estimates of aerosol radiative forcing from the MACC re-analysis. Atmos Chem Phys. 2013;13(4):2045-62. https://doi.org/10.5194/acp13-2045-2013.

109. Myhre G. Consistency between satellite-derived and modeled estimates of the direct aerosol effect. Science. 2009;325(5937):18790. https://doi.org/10.1126/science.1174461. 
110. Bellouin N, Boucher O, Haywood J, Reddy MS. Global estimate of aerosol direct radiative forcing from satellite measurements. Nature. 2005;438(7071):1138-41. https://doi.org/10.1038/ nature 04348 .

111. Kahn RA. Reducing the uncertainties in direct aerosol radiative forcing. Surv Geophys. 2012;33(3):701-21. https://doi.org/10. 1007/s10712-011-9153-z.

112. Holben BN, Eck TF, Slutsker I, Tanré D, Buis JP, Setzer A, et al. AERONET - a federated instrument network and data archive for aerosol characterization. Remote Sens Environ. 1998;66(1):1-16. https://doi.org/10.1016/s0034-4257(98)00031-5.

113. Dubovik O, King MD. A flexible inversion algorithm for retrieval of aerosol optical properties from sun and sky radiance measurements. J Geophys Res Atmos. 2000;105(D16):20673-96. https:// doi.org/10.1029/2000JD900282.

114. Samset BH, Myhre G, Forster P, Hodnebrog $\varnothing$, Andrews T, Boucher $\mathrm{O}$, et al. Weak hydrological sensitivity to temperature change over land, independent of climate forcing. npj Climate and Atmospheric Science. 2018;1. https://doi.org/10.1038/ s41612-017-0005-5.

115. Wang X, Heald CL, Ridley DA, Schwarz JP, Spackman JR, Perring AE, et al. Exploiting simultaneous observational constraints on mass and absorption to estimate the global direct radiative forcing of black carbon and brown carbon. Atmos Chem Phys Discuss. 2014;14(11):17527-83. https://doi.org/10.5194/ acpd-14-17527-2014.

116. Cohen JB, Wang C. Estimating global black carbon emissions using a top-down Kalman filter approach. J Geophys Res Atmos. n/a-n/a. 2013. https://doi.org/10.1002/2013jd019912.

117. Russell PB, Kacenelenbogen M, Livingston JM, Hasekamp OP, Burton SP, Schuster GL, et al. A multiparameter aerosol classification method and its application to retrievals from spaceborne polarimetry. J Geophys Res Atmos. 2014;119(16):9838-63. https://doi.org/10.1002/2013JD021411.

118. Andrews E, Ogren JA, Kinne S, Samset B. Comparison of AOD, AAOD and column single scattering albedo from AERONET retrievals and in situ profiling measurements. Atmos Chem Phys. 2017;17(9):6041-72. https://doi.org/10.5194/acp-17-6041-2017.

119. Kahn RA, Gaitley BJ, Martonchik JV, Diner DJ, Crean KA, Holben B. Multiangle Imaging Spectroradiometer (MISR) global aerosol optical depth validation based on 2 years of coincident Aerosol Robotic Network (AERONET) observations. J Geophys Res Atmos. 2005;110(D10). https://doi.org/10.1029/ 2004JD004706.

120. Mallet M, Dubovik O, Nabat P, Dulac F, Kahn R, Sciare J, et al. Absorption properties of Mediterranean aerosols obtained from multi-year ground-based remote sensing observations. Atmos Chem Phys. 2013;13(18):9195-210. https://doi.org/10.5194/acp13-9195-2013.

121. Kahn RA, Gaitley BJ, Garay MJ, Diner DJ, Eck TF, Smirnov A, et al. Multiangle Imaging SpectroRadiometer global aerosol product assessment by comparison with the Aerosol Robotic Network. J Geophys Res Atmos. 2010;115(D23). https://doi.org/10.1029/ 2010JD014601.

122. Kahn RA, Gaitley BJ. An analysis of global aerosol type as retrieved by MISR. J Geophys Res Atmos. 2015;120(9):4248-81. https://oi.org/10.1002/2015jd023322.

123. Limbacher JA, Kahn RA. MISR research-aerosol-algorithm refinements for dark water retrievals. Atmos Meas Tech. 2014;7(11):3989-4007. https://doi.org/10.5194/amt-7-39892014.

124. Limbacher JA, Kahn RA. Updated MISR dark water research aerosol retrieval algorithm—Part 1: coupled $1.1 \mathrm{~km}$ ocean surface chlorophyll a retrievals with empirical calibration corrections. Atmos Meas Tech. 2017;10(4):1539-55. https://doi.org/10.5194/ amt-10-1539-2017.
125. Li S, Kahn R, Chin M, Garay MJ, Liu Y. Improving satelliteretrieved aerosol microphysical properties using GOCART data. Atmos Meas Tech. 2015;8(3):1157-71. https://doi.org/10.5194/ amt-8-1157-2015.

126. Buchard V, Randles CA, da Silva AM, Darmenov A, Colarco PR, Govindaraju R, et al. The MERRA-2 Aerosol Reanalysis, 1980 onward. Part II: evaluation and case studies. J Clim. 2017;30(17): 6851-72. https://doi.org/10.1175/jcli-d-16-0613.1.

127. Buchard V, da Silva AM, Colarco PR, Darmenov A, Randles CA, Govindaraju R, et al. Using the OMI aerosol index and absorption aerosol optical depth to evaluate the NASA MERRA Aerosol Reanalysis. Atmos Chem Phys. 2015;15(10):5743-60. https:// doi.org/10.5194/acp-15-5743-2015.

128. Colarco PR, Nowottnick EP, Randles CA, Yi B, Yang P, Kim K$\mathrm{M}$, et al. Impact of radiatively interactive dust aerosols in the NASA GEOS-5 climate model: Sensitivity to dust particle shape and refractive index. J Geophys Res Atmos. 2014;119(2):753-86. https://doi.org/10.1002/2013jd020046.

129. Zhang L, Henze DK, Grell GA, Carmichael GR, Bousserez N, Zhang Q, et al. Constraining black carbon aerosol over Asia using OMI aerosol absorption optical depth and the adjoint of GEOSChem. Atmos Chem Phys. 2015;15(18):10281-308. https://doi. org/10.5194/acp-15-10281-2015.

130. Dubovik O, Lapyonok T, Litvinov P, Herman M, Fuertes D, Ducos F, et al. GRASP: a versatile algorithm for characterizing the atmosphere. SPIE Newsroom. 2014; https://doi.org/10.1117/2. 1201408.005558.

131. Torres B, Dubovik O, Fuertes D, Schuster G, Cachorro VE, Lapionak T, et al. Advanced characterization of aerosol properties from measurements of spectral optical depth using the GRASP algorithm. Atmos Meas Tech Discuss. 2016;2016:1-47. https:// doi.org/10.5194/amt-2016-334.

132. Peers F, Waquet F, Cornet C, Dubuisson P, Ducos F, Goloub P, et al. Absorption of aerosols above clouds from POLDER/ PARASOL measurements and estimation of their direct radiative effect. Atmos Chem Phys. 2015;15(8):4179-96. https://doi.org/ 10.5194/acp-15-4179-2015.

133. Peers F, Bellouin N, Waquet F, Ducos F, Goloub P, Mollard J, et al. Comparison of aerosol optical properties above clouds between POLDER and AeroCom models over the South East Atlantic Ocean during the fire season. Geophys Res Lett. 2016;43(8): 3991-4000. https://doi.org/10.1002/2016gl068222.

134. Torres O, Jethva H, Bhartia PK. Retrieval of aerosol optical depth above clouds from OMI observations: sensitivity analysis and case studies. J Atmos Sci. 2012;69(3):1037-53. https://doi.org/10. 1175/jas-d-11-0130.1.

135. Chand D, Anderson TL, Wood R, Charlson RJ, Hu Y, Liu Z, et al. Quantifying above-cloud aerosol using spaceborne lidar for improved understanding of cloudy-sky direct climate forcing. J Geophys Res Atmos. 2008;113(D13). https://doi.org/10.1029/ 2007JD009433.

136. Alterskjær K, Kristjánsson JE. The sign of the radiative forcing from marine cloud brightening depends on both particle size and injection amount. Geophys Res Lett. 2013;40(1):210-5. https:// doi.org/10.1029/2012GL054286.

137. Jethva H, Torres O, Remer LA, Bhartia PK. A color ratio method for simultaneous retrieval of aerosol and cloud optical thickness of above-cloud absorbing aerosols from passive sensors: application to MODIS measurements. IEEE Trans Geosci Remote Sens. 2013;51(17):3862-70. https://doi.org/10.1109/TGRS.2012. 2230008.

138. Meyer K, Platnick S, Zhang Z. Simultaneously inferring abovecloud absorbing aerosol optical thickness and underlying liquid phase cloud optical and microphysical properties using MODIS. J Geophys Res Atmos. 2015;120(11):5524-47. https://doi.org/10. 1002/2015JD023128. 
139. Sayer AM, Hsu NC, Bettenhausen C, Lee J, Redemann J, Schmid B, et al. Extending "Deep Blue" aerosol retrieval coverage to cases of absorbing aerosols above clouds: sensitivity analysis and first case studies. J Geophys Res Atmos. 2016;121(9):4830 54. https://doi.org/10.1002/2015JD024729.

140. Chang I, Christopher S. Identifying absorbing aerosols above clouds from the spinning enhanced visible and infrared imager coupled with NASA A-Train Multiple Sensors. IEEE T Geosci Remote. 2016;54(6):3163-73. https://doi.org/10.1109/TGRS. 2015.2513015.

141. Appel KW, Pouliot GA, Simon H, Sarwar G, Pye HOT, Napelenok SL, et al. Evaluation of dust and trace metal estimates from the Community Multiscale Air Quality (CMAQ) model version 5.0. Geosci Model Dev. 2013;6(4):883-99. https://doi.org/ 10.5194/gmd-6-883-2013.

142. Eckhardt S, Quennehen B, Olivié DJL, Berntsen TK, Cherian R, Christensen JH, et al. Current model capabilities for simulating black carbon and sulfate concentrations in the Arctic atmosphere: a multi-model evaluation using a comprehensive measurement data set. Atmos Chem Phys. 2015;15(16):9413-33. https://doi. org/10.5194/acp-15-9413-2015.

143. Koch D, Schulz M, Kinne S, McNaughton C, Spackman JR, Balkanski Y, et al. Evaluation of black carbon estimations in global aerosol models. Atmos Chem Phys. 2009;9(22):9001-26. https://doi.org/10.5194/acp-9-9001-2009.

144. Skeie RB, Berntsen T, Myhre G, Pedersen CA, Ström J, Gerland $\mathrm{S}$, et al. Black carbon in the atmosphere and snow, from preindustrial times until present. Atmos Chem Phys. 2011;11(14): 6809-36. https://doi.org/10.5194/acp-11-6809-2011.

145. Xing J, Mathur R, Pleim J, Hogrefe C, Gan CM, Wong DC, et al. Observations and modeling of air quality trends over 1990-2010 across the Northern Hemisphere: China, the United States and Europe. Atmos Chem Phys. 2015;15(5):2723-47. https://doi.org/ 10.5194/acp-15-2723-2015.

146. Sharma S, Ishizawa M, Chan D, Lavoué D, Andrews E, Eleftheriadis K, et al. 16-year simulation of Arctic black carbon: transport, source contribution, and sensitivity analysis on deposition. J Geophys Res Atmos. 2013;118(2):943-64. https://doi.org/ 10.1029/2012jd017774.

147. Collaud Coen M, Andrews E, Asmi A, Baltensperger U, Bukowiecki N, Day D, et al. Aerosol decadal trends - part 1: insitu optical measurements at GAW and IMPROVE stations. Atmos Chem Phys. 2013;13(2):869-94. https://doi.org/10.5194/ acp-13-869-2013.

148. Sherman JP, Sheridan PJ, Ogren JA, Andrews E, Hageman D, Schmeisser L, et al. A multi-year study of lower tropospheric aerosol variability and systematic relationships from four North American regions. Atmos Chem Phys. 2015;15(21):12487-517. https://doi.org/10.5194/acp-15-12487-2015.

149. Corrigan CE, Roberts GC, Ramana MV, Kim D, Ramanathan V. Capturing vertical profiles of aerosols and black carbon over the Indian Ocean using autonomous unmanned aerial vehicles. Atmos
Chem Phys. 2008;8(3):737-47. https://doi.org/10.5194/acp-8737-2008.

150. Oshima N, Kondo Y, Moteki N, Takegawa N, Koike M, Kita K, et al. Wet removal of black carbon in Asian outflow: Aerosol Radiative Forcing in East Asia (A-FORCE) aircraft campaign. J Geophys Res Atmos. 2012;117(D3):n/a-n/a) https://doi.org/10. 1029/2011JD016552.

151. Allan JD, Morgan WT, Darbyshire E, Flynn MJ, Williams PI, Oram DE, et al. Airborne observations of IEPOX-derived isoprene SOA in the Amazon during SAMBBA. Atmos Chem Phys. 2014;14(20):11393-407. https://doi.org/10. 5194/acp-14-11393-2014.

152. Schutgens NAJ, Gryspeerdt E, Weigum N, Tsyro S, Goto D, Schulz M, et al. Will a perfect model agree with perfect observations? The impact of spatial sampling. Atmos Chem Phys. 2016;16(10):6335-53. https://doi.org/10.5194/acp-166335-2016.

153. Reddington CL, Carslaw KS, Stier P, Schutgens N, Coe H, Liu D, et al. The Global Aerosol Synthesis and Science Project (GASSP): measurements and modeling to reduce uncertainty. B Am Meteorol Soc. 2017;98(9):1857-77. https://doi.org/10.1175/ bams-d-15-00317.1.

154. McMeeking GR, Good N, Petters MD, McFiggans G, Coe H. Influences on the fraction of hydrophobic and hydrophilic black carbon in the atmosphere. Atmos Chem Phys. 2011;11(10):5099 112. https://doi.org/10.5194/acp-11-5099-2011.

155. Schwarz JP, Perring AE, Markovic MZ, Gao RS, Ohata S, Langridge $J$, et al. Technique and theoretical approach for quantifying the hygroscopicity of black-carbon-containing aerosol using a single particle soot photometer. J Aerosol Sci. 2015;81:110-26. https://doi.org/10.1016/j.jaerosci.2014.11.009.

156. Andrews E, Sheridan PJ, Ogren JA. Seasonal differences in the vertical profiles of aerosol optical properties over rural Oklahoma. Atmos Chem Phys. 2011;11(20):10661-76. https://doi.org/10. 5194/acp-11-10661-2011.

157. Sheridan PJ, Andrews E, Ogren JA, Tackett JL, Winker DM. Vertical profiles of aerosol optical properties over central Illinois and comparison with surface and satellite measurements. Atmos Chem Phys. 2012;12(23):11695-721. https://doi.org/10.5194/ acp-12-11695-2012.

158. Kahn RA, Berkoff TA, Brock C, Chen G, Ferrare RA, Ghan S, Hansico TF, Hegg DA, Martins JV, McNaughton CS, Murphy DM, Ogren JA, Penner JE, Pilewskie P, Seinfeld JH, Worsnop DR. SAM-CAAM: a concept for acquiring systematic aircraft measurements to characterize aerosol air masses. Bull Amer Meteor Soc. 2017;98:2215-28. https://doi.org/10.1175/BAMSD-16-0003.1.

159. Kahn RA, Chen Y, Nelson DL, Leung F-Y, Li Q, Diner DJ, et al. Wildfire smoke injection heights: two perspectives from space. Geophys Res Lett. 2008;35(4). https://doi.org/10.1029/ 2007GL032165. 